\title{
Potential clinical biomarkers in rheumatoid arthritis with an omic approach
}

\author{
Yolima Puentes-Osorio ${ }^{1,5^{*}}$ (0), Pedro Amariles ${ }^{1}$, Miguel Ángel Calleja², Vicente Merino², \\ Juan Camilo Díaz-Coronado ${ }^{3}$ and Daniel Taborda ${ }^{4}$
}

\begin{abstract}
Objective: To aid in the selection of the most suitable therapeutic option in patients with diagnosis of rheumatoid arthritis according to the phase of disease, through the review of articles that identify omics biological markers.

Methods: A systematic review in PubMed/Medline databases was performed. We searched articles from August 2014 to September 2019, in English and Spanish, filtered by title and full text; and using the terms "Biomarkers" AND "Rheumatoid arthritis".

Results: This article supplies an exhaustive review from research of objective measurement, omics biomarkers and how disease activity appraise decrease unpredictability in treatment determinations, and finally, economic, and clinical outcomes of treatment options by biomarkers' potential influence. A total of 122 articles were included. Only 92 met the established criteria for review purposes and 17 relevant references about the topic were included as well. Therefore, it was possible to identify 196 potential clinical biomarkers: 22 non-omics, 20 epigenomics, 33 genomics, 21 transcriptomics, 78 proteomics, 4 glycomics, 1 lipidomics and 17 metabolomics.

Conclusion: A biomarker is a measurable indicator of some, biochemical, physiological, or morphological condition; evaluable at a molecular, biochemical, or cellular level. Biomarkers work as indicators of physiological or pathological processes, or as a result of a therapeutic management. In the last five years, new biomarkers have been identified, especially the omics, which are those that proceed from the investigation of genes (genomics), metabolites (metabolomics), and proteins (proteomics). These biomarkers contribute to the physician choosing the best therapeutic option in patients with rheumatoid arthritis.
\end{abstract}

Keywords: Rheumatoid arthritis, Genomics, Proteomics, Treatment, Omics, Biomarkers, Pharmacogenomics, Metabolomics, Polymorphism, Stages

\section{Relevance}

- We could associate a better outcome in the patient's treatments reducing unpredictability of the management.
${ }^{*}$ Correspondence: yolimap16@gmail.com

${ }^{5} 41009$ Sevilla, Spain

Full list of author information is available at the end of the article
- We made a review searching for the biomarkers associated with the different phases of rheumatoid arthritis.

\section{Introduction}

Rheumatoid arthritis (RA) is a chronic autoimmune disease which is progressive and often disabling characterized by joint inflammation and pain; it requires monitoring of disease activity to decide the optimal treatment. Decreased quality of life, reduction of function and work

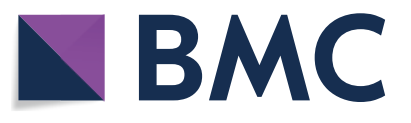

(c) The Author(s) 2021. This article is licensed under a Creative Commons Attribution 4.0 International License, which permits use, sharing, adaptation, distribution and reproduction in any medium or format, as long as you give appropriate credit to the original author(s) and the source, provide a link to the Creative Commons licence, and indicate if changes were made. The images or other third party material in this article are included in the article's Creative Commons licence, unless indicated otherwise in a credit line to the material. If material is not included in the article's Creative Commons licence and your intended use is not permitted by statutory regulation or exceeds the permitted use, you will need to obtain permission directly from the copyright holder. To view a copy of this licence, visit http://creativeco mmons.org/licenses/by/4.0/. 
participation are associated with mental and physical health of the patients. The use of biomarkers as monitors of disease development may aid providers improve non-biologic and biologic drugs [1]. Biomarkers have the capacity to enhance payment for medical and pharmacy policies related with the therapeutic management in immune system disorders and inflammatory diseases; they also has a potential impact on economic and clinical outcomes of treatment choices [2].

The aim of RA therapy is to keep and increase a prolonged state of health associated with quality of life by controlling symptoms, preventing structural joint damage, normalizing physical function, and getting better function in their activities. However, in patients with $\mathrm{RA}$, treated either with methotrexate or biologic disease-modifying anti-rheumatic drugs (DMARDs), only $40-60 \%$ of them respond effectively as measured by at least $50 \%$ of improvement of signs and symptoms of the disease (by ACR criteria), whereas 15-30\% develop adverse drug events [3].

On the other hand, in 2013 it was reported a systematic review of the International Journal of Rheumatology that approximately $50 \%$ of RA patients in Europe interrupted their biological therapy of the TNF inhibitor group during the first five years of use as a result of ineffectiveness or adverse drug reactions [4]. Similarly, a study in Boston at BRASS (Brigham and Women's Hospital Rheumatoid Arthritis Sequential Study) showed that $42 \%$ of patients with RA reported abandonment of their anti-TNF therapy due to ineffectiveness [5]. Hence, biomarkers could become a tool with greater capacity to predict the health results of therapeutic applications to expand them beyond early detection, timely evaluation of a prognosis, and selection of the most effective and safest therapy, as well as monitoring disease activity, resulting in greater preservation of joint space and motility of the RA patients [6].

RA is a major current public health problem, in terms of deterioration in the quality of life and the generation of high costs for the health system. Although in recent years, better health results have been achieved with the incorporation of disease modifying drugs (synthetic and biological), it is evident that there is a need to better redirect resources and take advantage of the window of opportunity of the disease.

Pharmacokinetics and pharmacodynamics of drugs, becomes a fundamental and additional instrument to those already existing, which allows us to determine the choice of a more effective and safer drug that meets the particular needs of the patient. Genetic information is expressed at the level of proteins and metabolites; therefore, it is necessary to determine specific predictors or biomarkers for different phases of rheumatoid arthritis, especially the OMICS that include pharmacogenomics, metabolomics, and proteomics (Fig. 2).

\section{Omics-based biomarkers classification}

Biomarkers are interaction parameters that provide information on an objectively measurable physiological, biochemical, or morphological change that can be evaluable at the molecular, biochemical or cellular level and that acts as an indicator of a functional biological process or a pathogenic state, or as a response to medical treatment [7]. Biological markers are conceived as physiological signals induced by a xenobiotic, which is a cellular exposure, a precocious cellular response, or an inherent or acquired susceptibility [8].

Biomarkers are classified according to the information they provide and according to their nature. These biomarkers are important for identification of individuals in a population, that may be sensitive to a certain health problem. These kinds of biomarkers are classified as biomarkers of exposure, effect and susceptibility.

Exposure biomarkers evaluate the presence in an organism of an exogenous substance, a metabolite or product of the interaction between xenobiotic agent (natural or synthetic compounds of the environment that organism metabolizes and accumulates) and a molecule or target cell.

Prognostic Biomarkers report about progression of disease; this is, if disease improves or worsens after corresponding treatment. EphB4 membrane receptor is a prognostic biomarker of colon cancer [7].

Biomarkers of susceptibility are indicators of the inherited or acquired capacity of a given organism to respond to exposure to xenobiotic substances.

Biomarkers according to their nature are classified into omics that come from the study of genes (genomics), proteins (proteomics) and metabolites (metabolomics); epigenetics that come from changes that occur in DNA and that are related to some pathology, and microRNA molecules that are expressed in different amounts in either normal or cancerous cells (genomics/transcriptomics) [9].

According to the Food and Drug Administration, biomarkers are classified as follows $[10,11]$ :

- Diagnostic biomarker: used to detect or confirm presence of a disease or certain condition, or to identify individuals with a subtype of disease. For example: HbA1c is commonly the most used biomarker to diagnose prediabetes and diabetes [12].

- Prognostic biomarker: used to identify probability of a clinical event, disease recurrence or progression in patients with a diagnosis of a disease or medical condition of interest. For example: 
increasing prostate-specific antigen (PSA) as predictor of clinical progression for prostate cancer [13].

- Safety biomarker: used to indicate the likelihood, presence, or extent of toxicity as an adverse effect measured before or after exposure to a medical product or derived from environmental causes. For example: transaminases have been selected as biomarkers for potentially hepatotoxic drugs [14].

- Monitoring biomarker: measured in series to assess the level of a disease or medical condition, or the evidence of exposure to (or the effect of) a medical product or environmental agent. For example: B-type natriuretic peptide as a measure of vascular and ventricular function in pediatric pulmonary arterial hypertension [15].

- Pharmacodynamic response biomarker: used to demonstrate that in exposition to medical products or environmental causes in an individual there is a biological reaction. For example: International Standardized Ratio (INR) for anticoagulant treatment, which has special interest in the adjustment of drug [16].

Ideal biomarkers should provide diagnostic, prognostic, and therapeutic information; additionally, they have to be obtainable from patient's clinical data, and should possess chemical-analytical characteristics such as:

- High specificity: measurement of a biomarker must be specific to a disease.

- Specimen: collection of samples should be minimally invasive. For example, saliva is better than urine and urine better than blood.

- Representativeness: levels of biomarkers in the selection sample should be representative of levels of biomarkers in the organism.

- Stability: kinetics must be known [17].

Regarding pharmacological safety of patients, ideal biomarkers should be aimed at health care processors. So, it is advisable to guide pharmacotherapeutic follow-up and programs for appropriate use of drugs through these pointing elements (tracers or markers). In this sense, detection of these elements is highly recommended, by means of information systems (systematized monitoring of warning signals), such as: identification of some medications, laboratory tests, symptoms or diagnoses and medical notes or phrases in clinical histories, known as markers or bookmarks [18].

\section{Materials and methods}

A systematic review was performed in PubMed/Medline databases. We searched articles from August 2014 to September 2019, in English and Spanish, filtered by title, full text, and using the terms "biomarkers" AND "Rheumatoid Arthritis". Inclusion criteria defined articles that reported biomarkers in different phases of rheumatoid arthritis and drug specific uses (Fig. 1).

Data extraction was performed on articles that met the inclusion criteria. Articles were downloaded and analyzed according to predefined eligibility criteria in a systematic review database. A format was created with reference, omics biomarker, phase of the disease, and a short description of potential use in clinical practice.

\section{Results}

A total of 122 articles were included, only 92 met established criteria for review purposes and 17 relevant references about the topic were included. Therefore, it was possible to identify 196 potential clinical biomarkers: 22 non-omics, 20 epigenomics, 33 genomics, 21 transcriptomics, 78 proteomics, 4 glycomics, 1 lipidomics and 17 metabolomics. Figure 1 shows screening carried out concluding in the identification of different types of omics biomarkers.

In addition, Fig. 2 shows different states of rheumatoid arthritis from the beginning with asymptomatic autoimmunity until joint destruction. Also, six phases of RA treatment are shown, and types of omics biomarkers are identified.

Consequently, identifying and monitoring biomarkers in different phases of disease will help to improve diagnosis, treatment, and quality of life of patients with RA.

Thus, this review identified both omic and non-omic biomarkers in each phase of RA. Table 1 shows a brief description of each biomarker and number of biomarkers identified in each phase of rheumatoid arthritis. For example, in phase 1 of RA were identified twenty-three biomarkers, in phase 2 seventeen, in phase 3 forty-one, in phase 4 eighteen, in phase 5 forty-nine, and in phase 6 forty-one.

Finally, Table 1 shows biomarkers that can be used as predictors of response to drugs used for treatment of rheumatoid arthritis.

\section{Discussion}

Current overview of omics-based biomarkers of rheumatoid arthritis in clinical practice

In 2010, new criteria for early classification of RA were published as a joint effort of the European League against Rheumatism/American College of Rheumatology (EULAR) and the American College of Rheumatology 


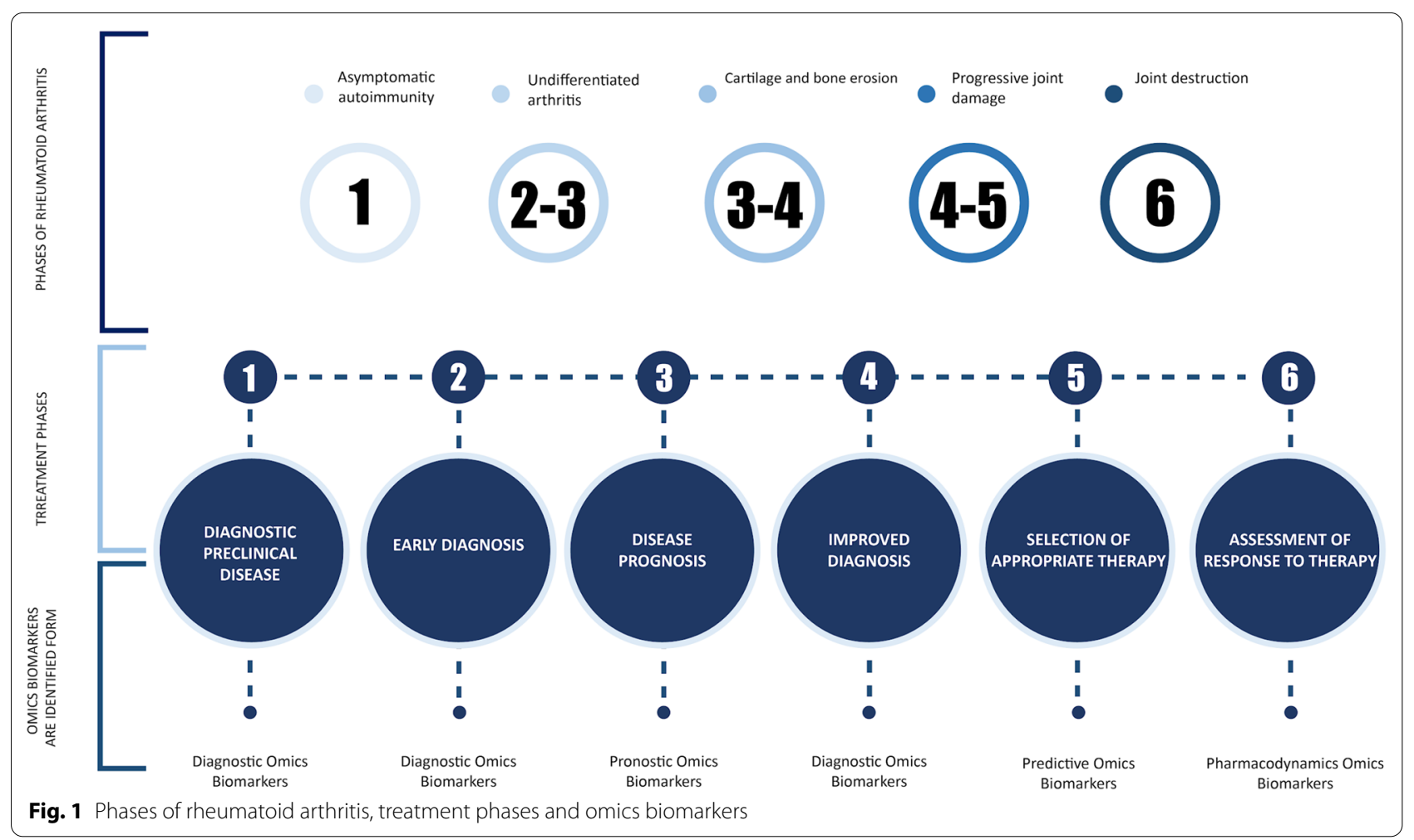

(ACR), with the objective to improve the classification in diagnosis based on existing criteria. It was also proposed as a tool to take advantage of therapeutic opportunity in early stages of disease. On the other hand, these new criteria highlight the importance of using biomarkers to support therapeutic decisions in the clinical field [126].

Within these new clinical findings, rheumatoid factor (RF), anti-cyclic citrullinated peptide (ACPA) and acute phase reactants (APR) are so far the most commonly used biomarkers in clinical settings to guide diagnosis and prognosis of RA. And since its description in 1940, RF continues being the most used laboratory tool for diagnosis and prognosis of RA in early stages of disease. However, its use and interpretation has been conditioned since the appearance of ACPAs as more specific markers (95\% -98\% vs. $85 \%$ ) and similarly sensitive than RF (60$80 \%$ vs. $65 \%-80 \%)$. In addition, the value of ACPA can predict development of disease and response to specific therapies (high levels-low levels).

Despite their wide use, both RF and ACPA, as well as APR (they are nonspecific of the RA and sometimes they do not change with progression) have proved to be insufficient to respond satisfactorily to the high heterogeneity of RA. However, in the last five years omic approaches have had a gradual and homogeneous increase in the discovery and proposal of new biomarkers that could solve difficult questions about decision making in clinical settings.

Consequently, the so far approved biomarker is ideal and robust enough to be the only clinical criteria for diagnosis or prediction of disease with high reliability, specificity, and sensitivity. In this case, not only a biomarker but also a panel or group of biomarkers -that reflect the multifactor nature of the disease state of RA-should be considered. At present, the right choice of candidate biomarkers offers additional and objective information that, when used in conjunction with traditional tools and techniques, represents a potential opportunity to make more informed and integrative clinical decisions that lead to a more precise medical care model. This model will allow stratification of RA patients according to the level of risk and degree of therapeutic opportunity.

In this sense, a patient can benefit from previous diagnosis, stratification in response to severity of disease progress, prediction of response to a specific therapy, and prediction of toxicity reactions or identification of prognostic value avoiding ineffective treatments which can favor exposure to side effects. This allows access to timely care that improves the quality of life and better control of disease, offers a valuable degree of prevention, reduces costs to the health system, and contributes to the possibility of developing new therapies (Table 2). 


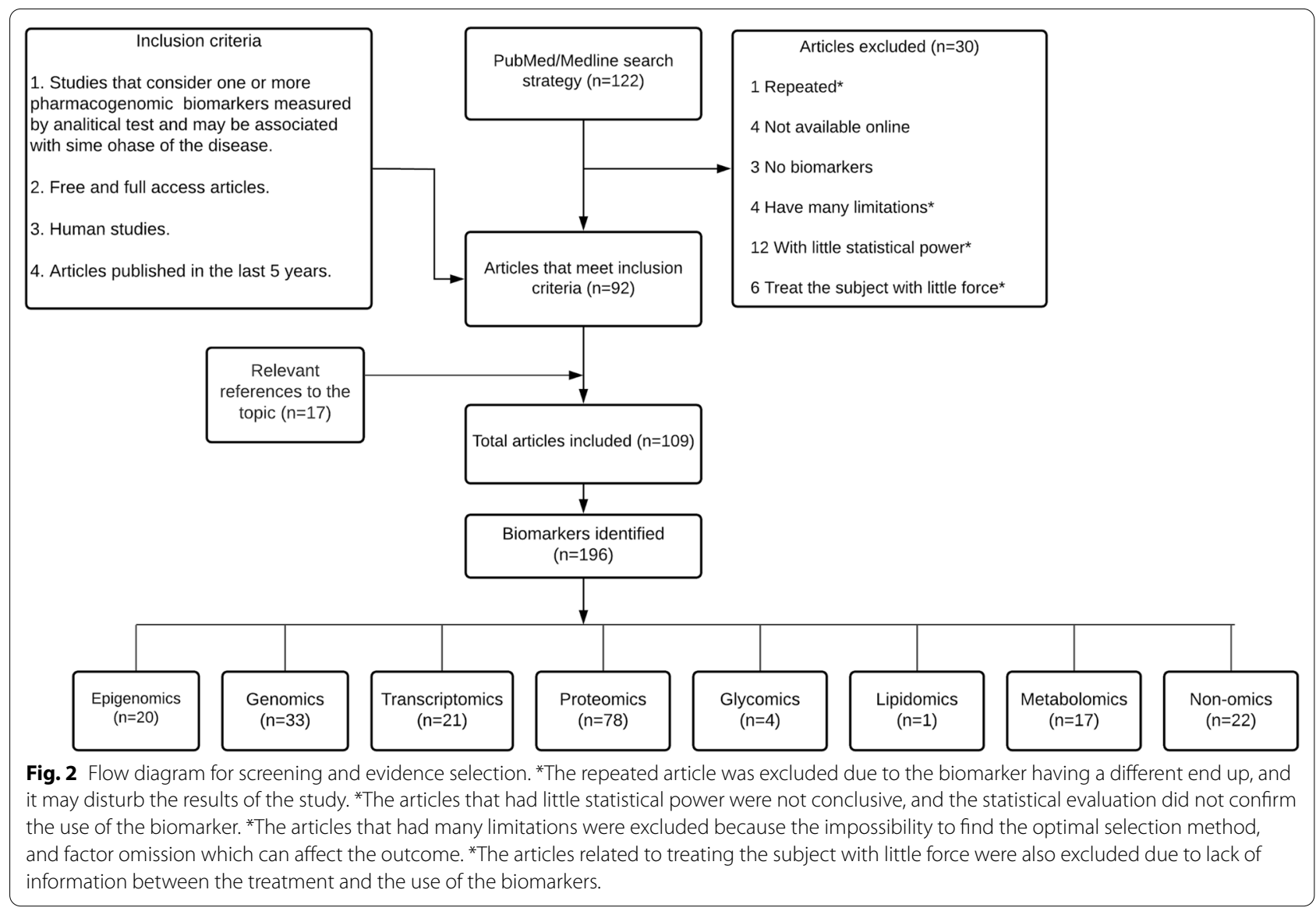

Among the phase 1 biomarkers possess both protective and present actions in patients at risk for RA, this in RF-positive and RF-negative patients. In particular cases such as calgranulin $\mathrm{C}$ provides a differentiating characteristic against other inflammatory arthritis (Table 1). As for those proteomics and metabolomics are characterized by their use as clinical diagnostics, and differentiation between RA patients and healthy patients.

The most common associations found in this phase are associated with rapid joint destruction and disease progression. However, there are some omic-biomarkers related with positive outcomes as the requirement of less therapeutic interventions like M1V variant SNP (Table 1). Most of these changes can be assessed by radiological findings.

The major feature that stands out among the phase 6 biomarkers is that they are correlated to treatment response, both for increasing and decreasing biomarker concentration. Their presence can serve as an indicator and predictor of response to treatment with antiTNF biologic drugs such as ICAM-1. In particular those genomic biomarkers within this phase have an association with reduced disease activity in early RA, for example sTNFRII which is associated with disease remission after treatment with tocilizumab. Among the phase 6 proteomics, relationships are found between a high concentration and clinical response to infliximab such as MMP-3 (Table 1).

\section{Perspectives and challenges of the use of omics-based biomarkers in clinical practice}

Although numerous publications about the discovery of new biomarkers are available, currently, their translation into clinical practice is limited. However, progressive growth of technologies and omic sciences and interest of international organizations such as FDA/EMA, have allowed a better outlook to the use of biomarkers as useful tools to improve quality of healthcare.

Even so, it is necessary to identify and recognize a series of barriers and challenges that must be worked on to have a greater number of biomarkers. In this regard, the following stand out:

- Omics technologies and costs. Although technology is in rapid and progressive growth, they are still expensive. 


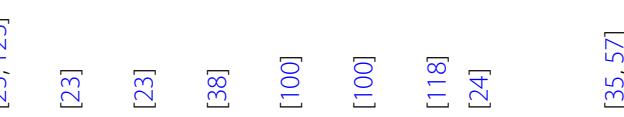

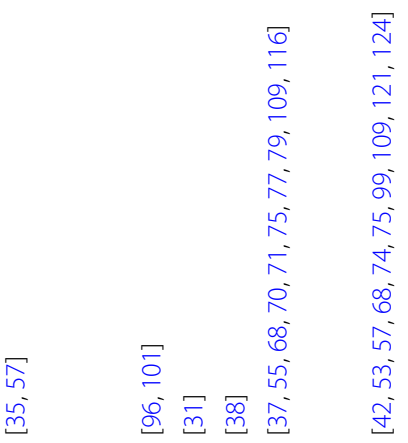

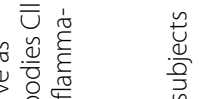

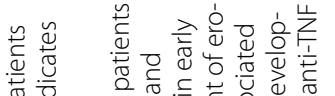

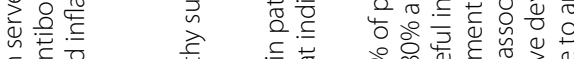

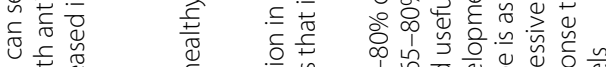

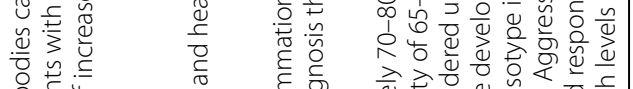

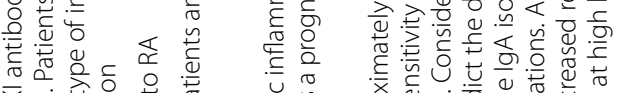

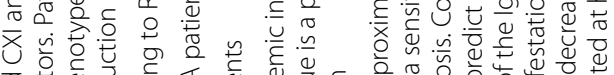

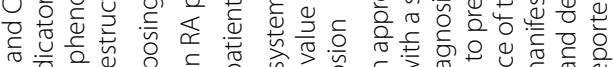

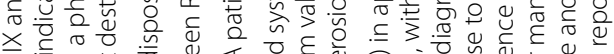

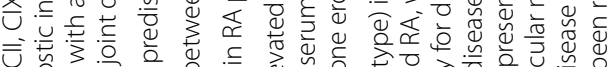

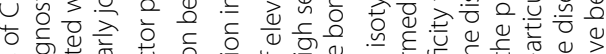

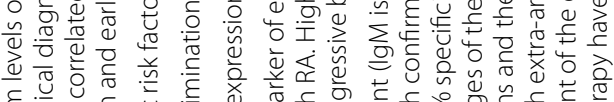

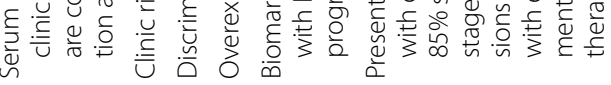

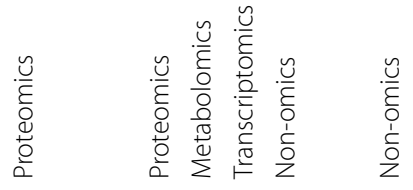

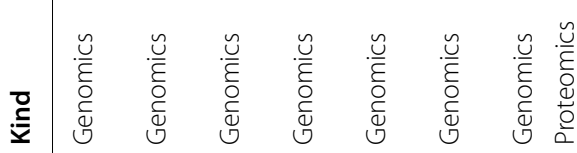

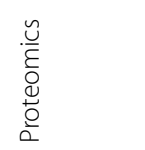

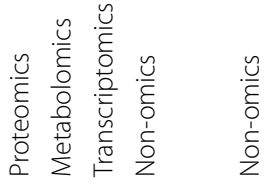

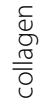<smiles>C1CCCC1</smiles>

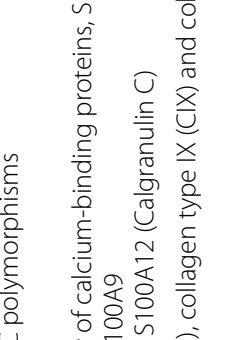

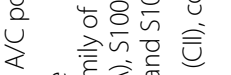

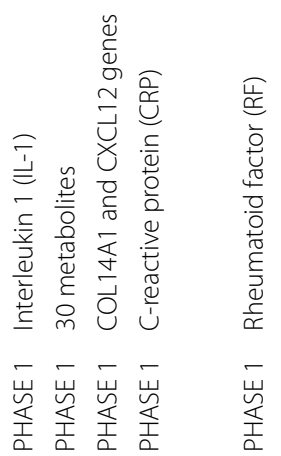




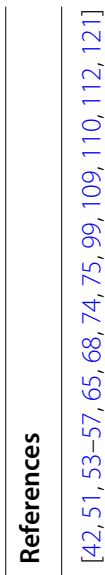

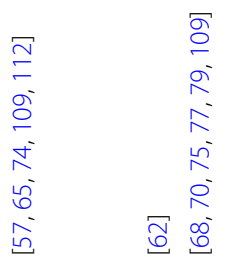

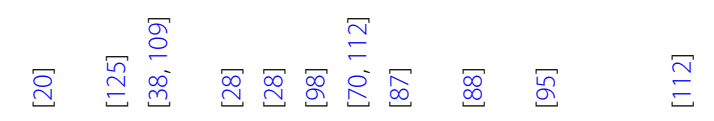

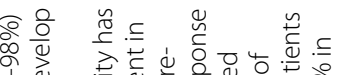

ì

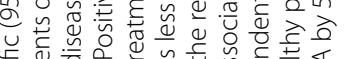

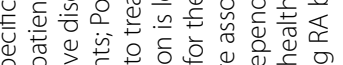

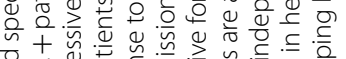

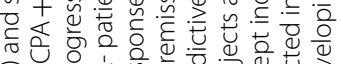

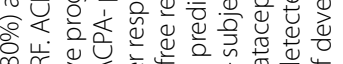

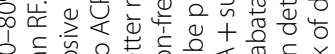

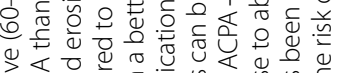

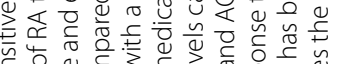

$\subseteq$

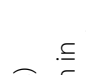

索导

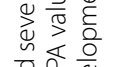

剀

बै

장

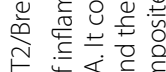

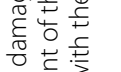

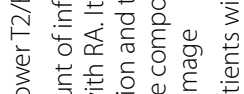

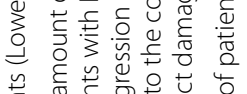

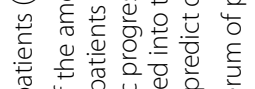

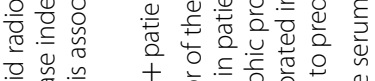

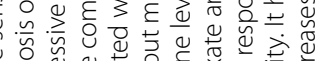

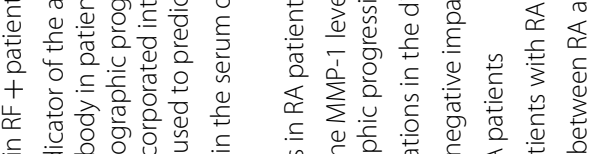

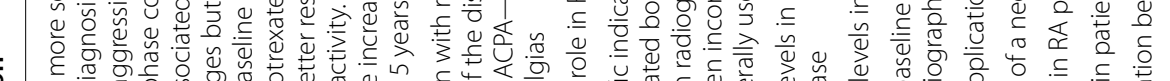

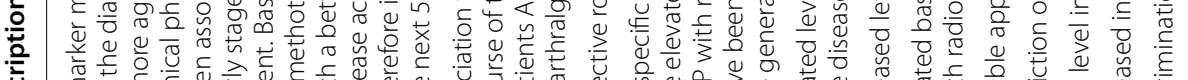

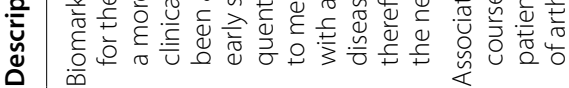

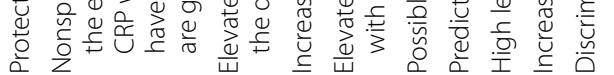

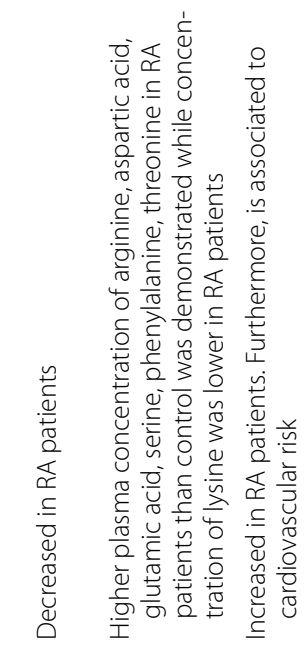

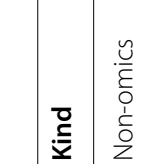

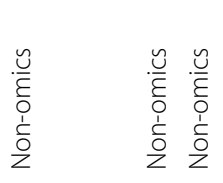

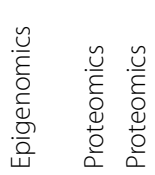

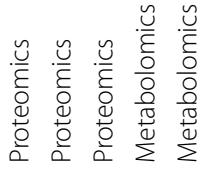

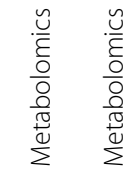

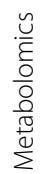


ॠ

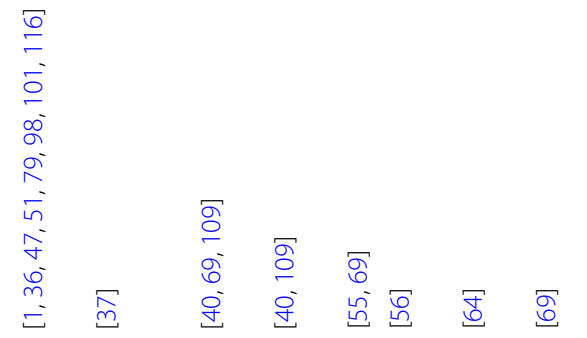

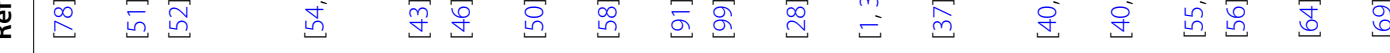

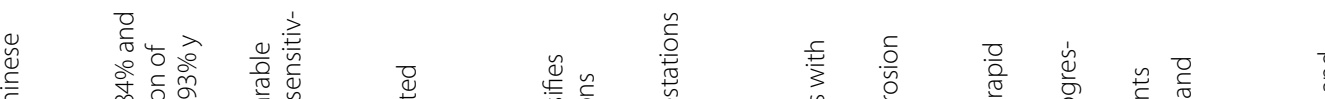

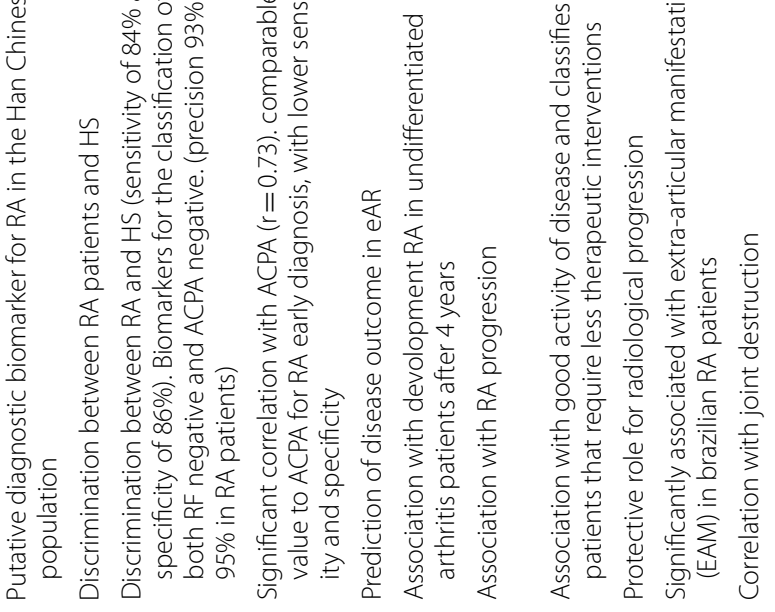

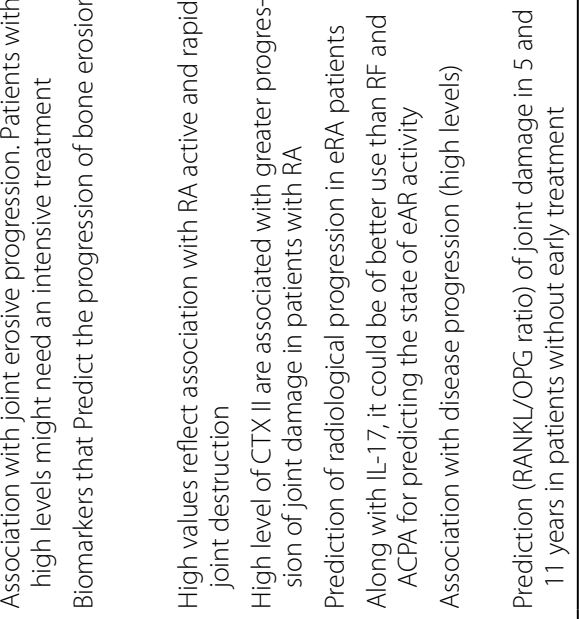

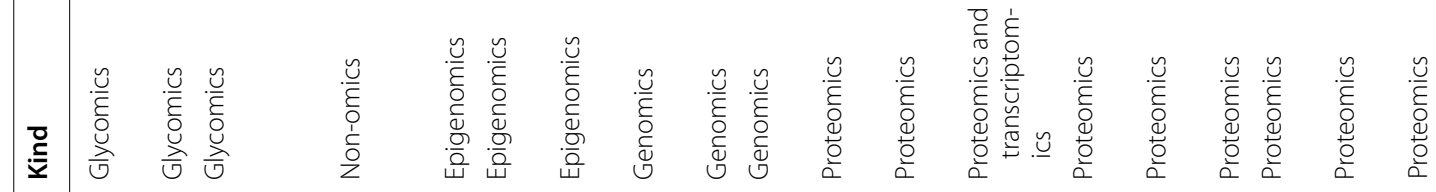

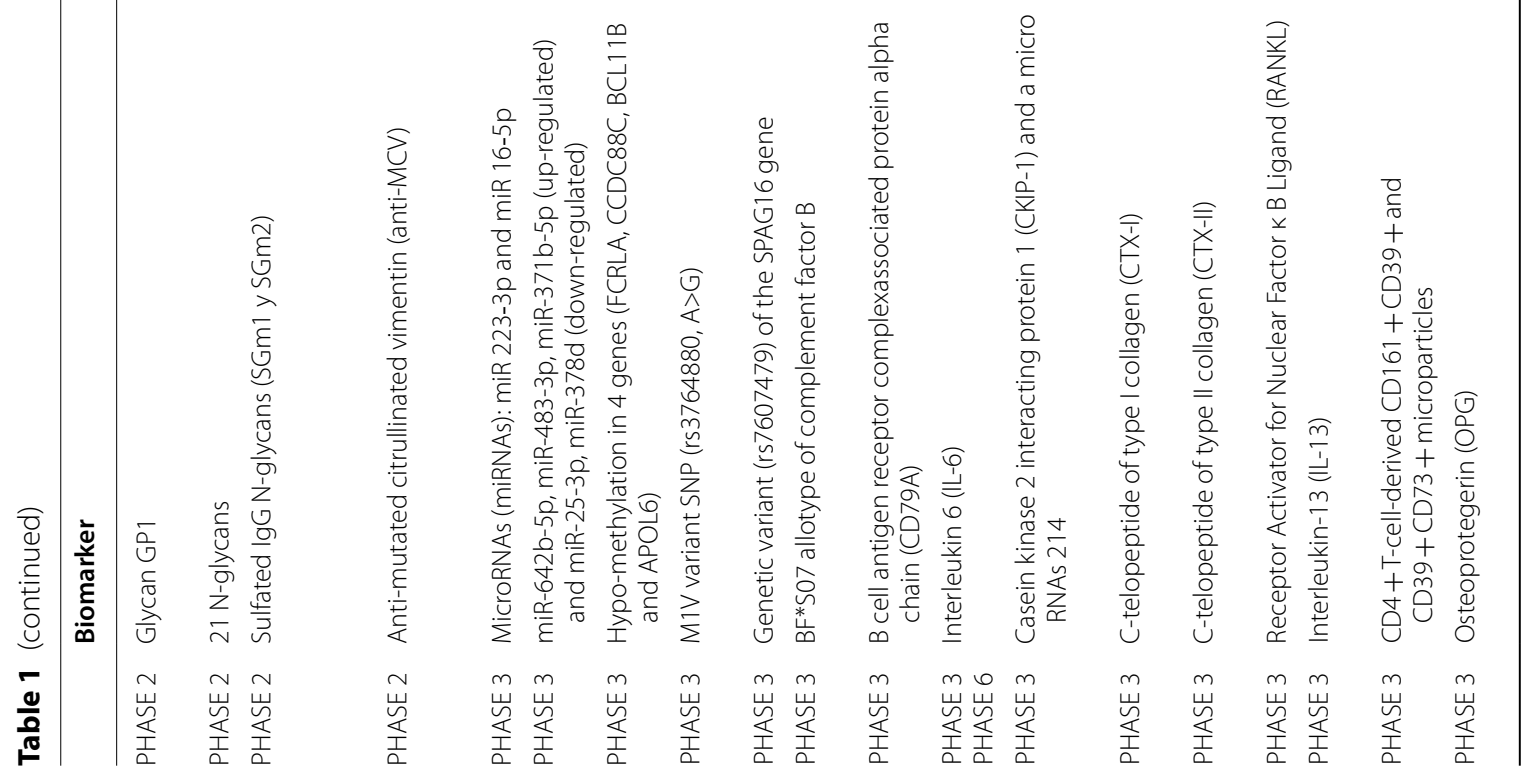




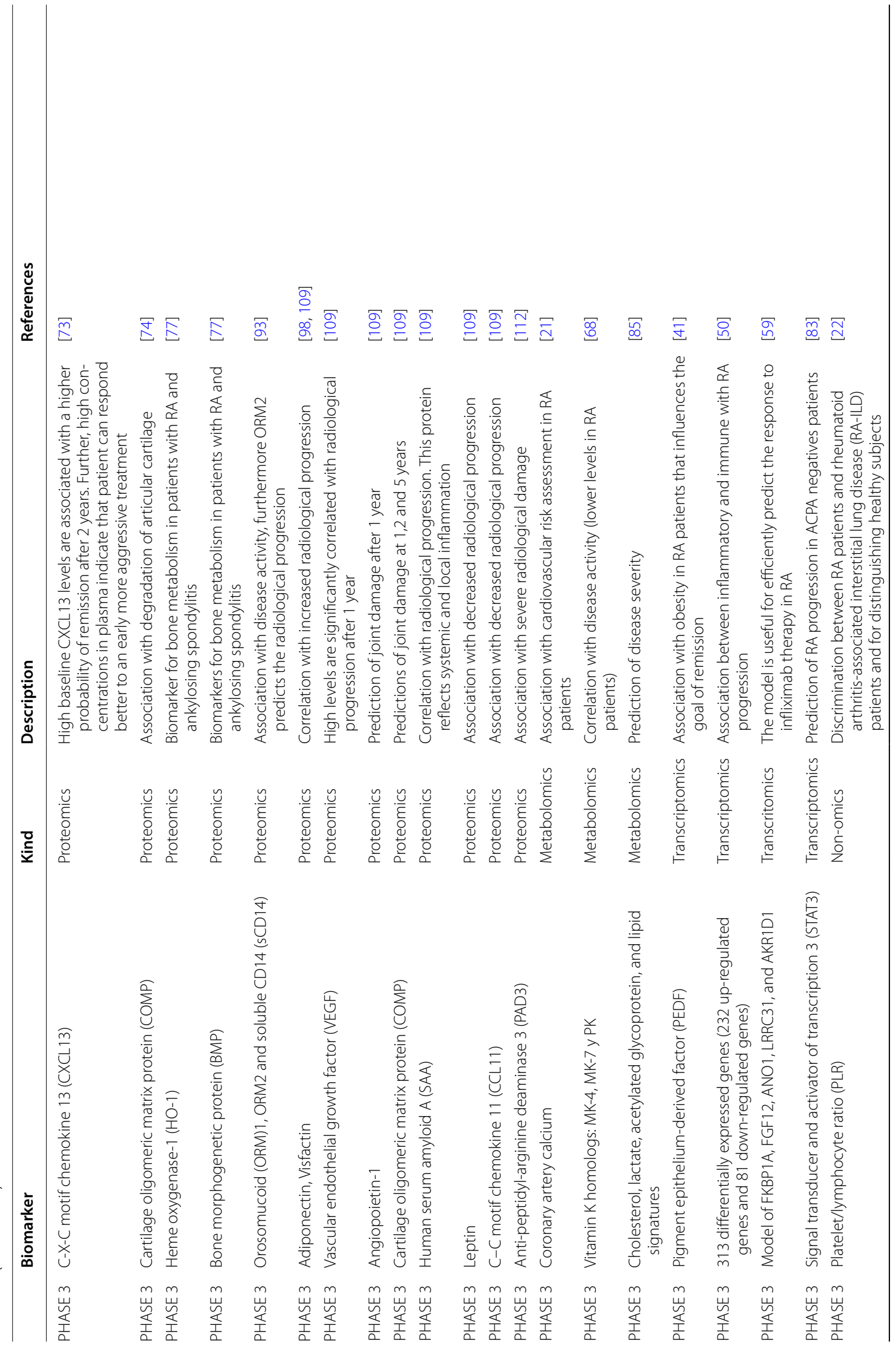




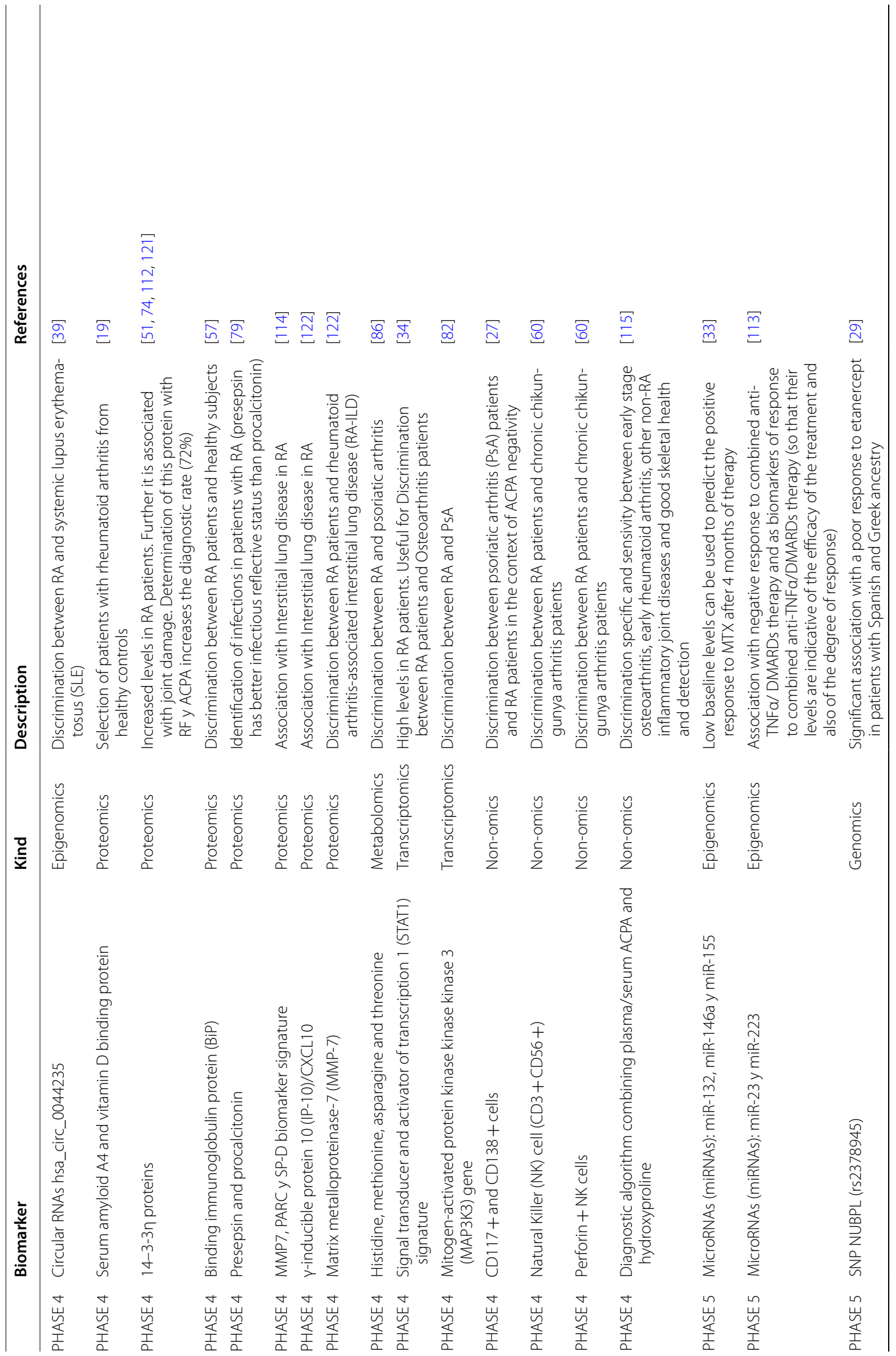




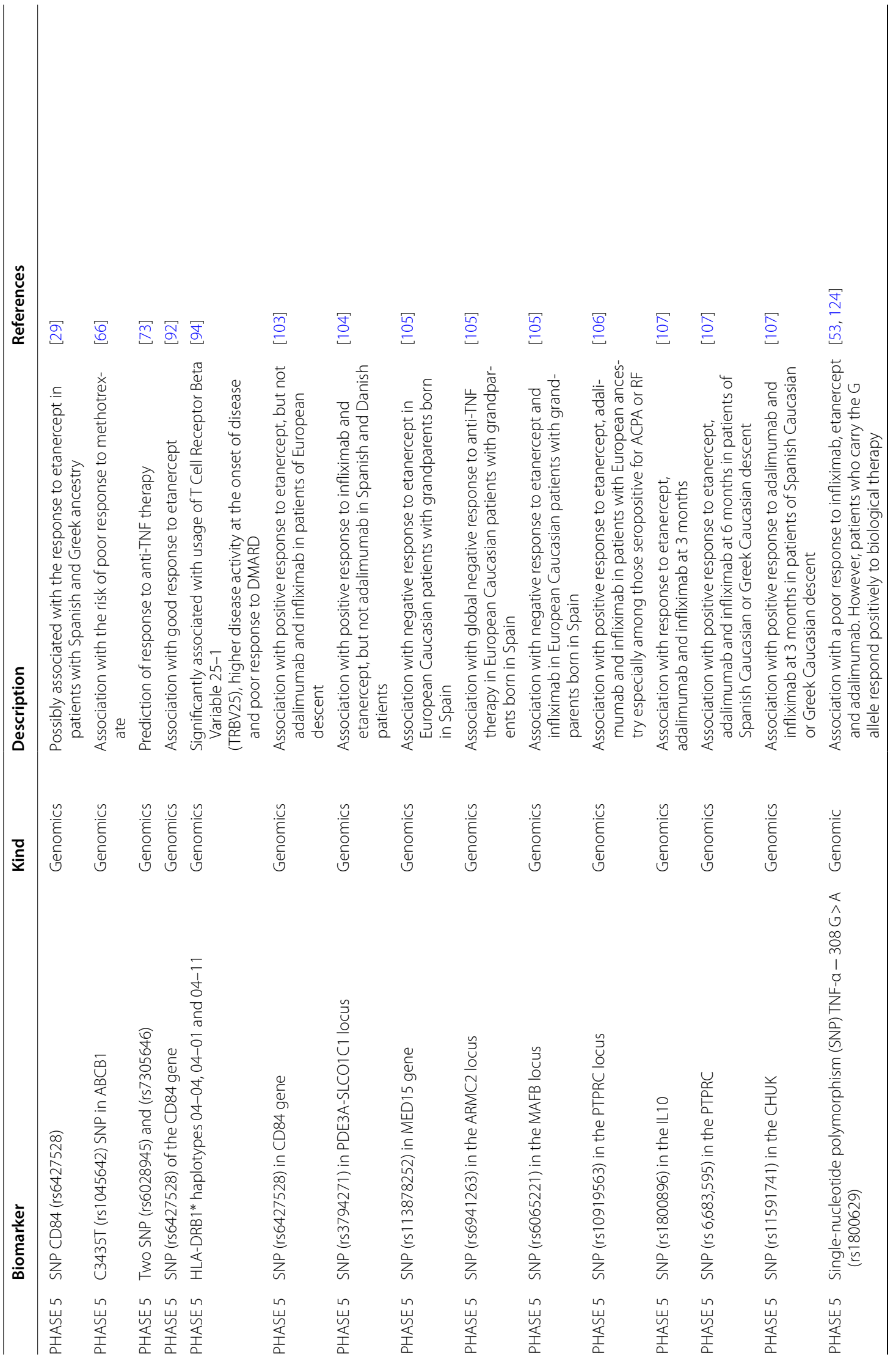




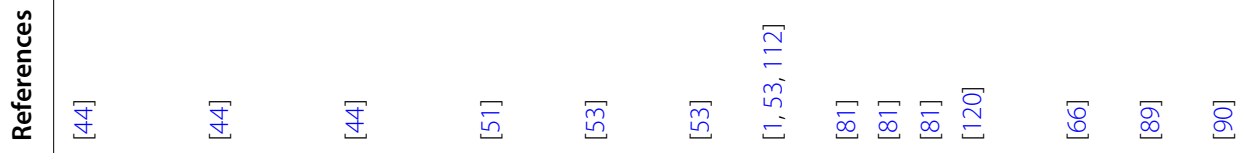

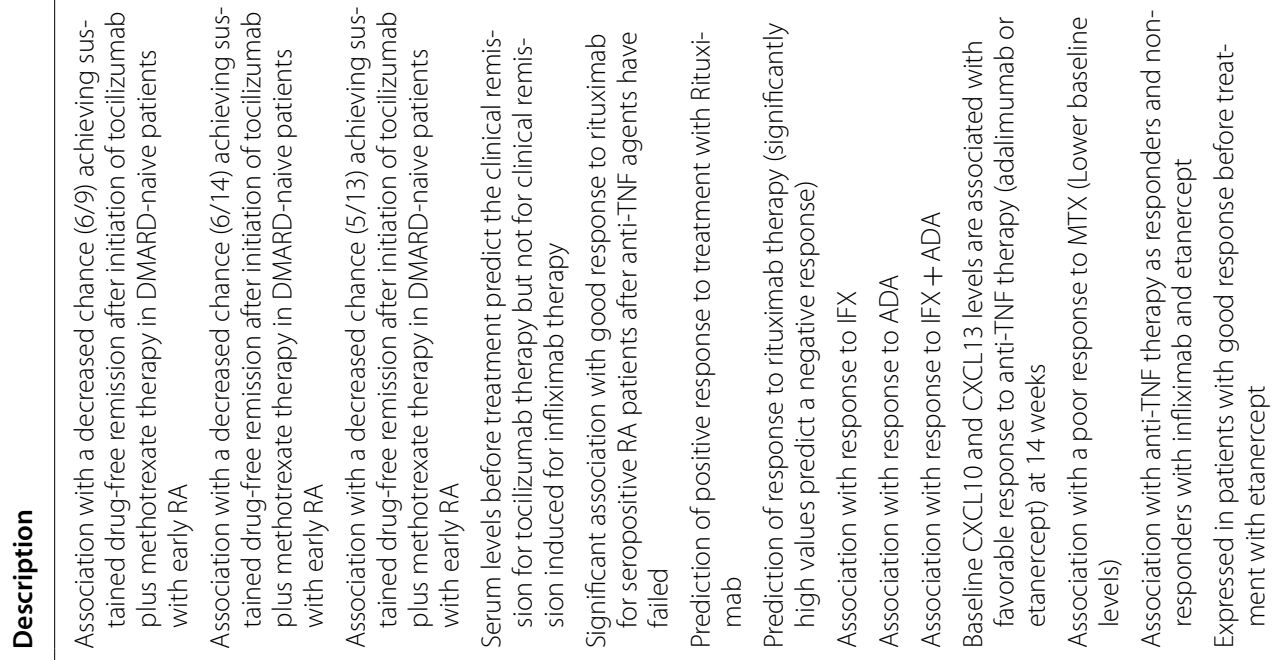

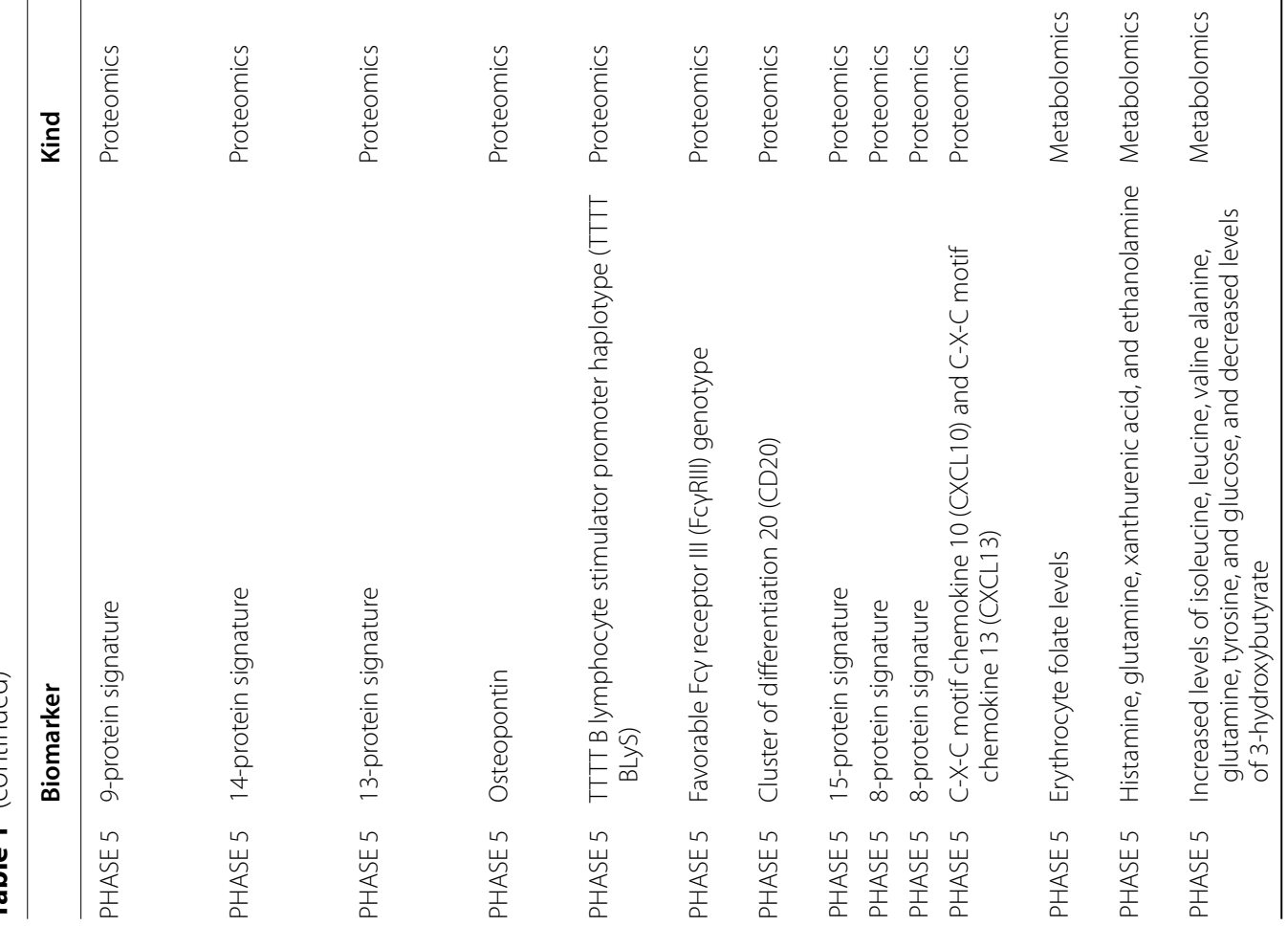




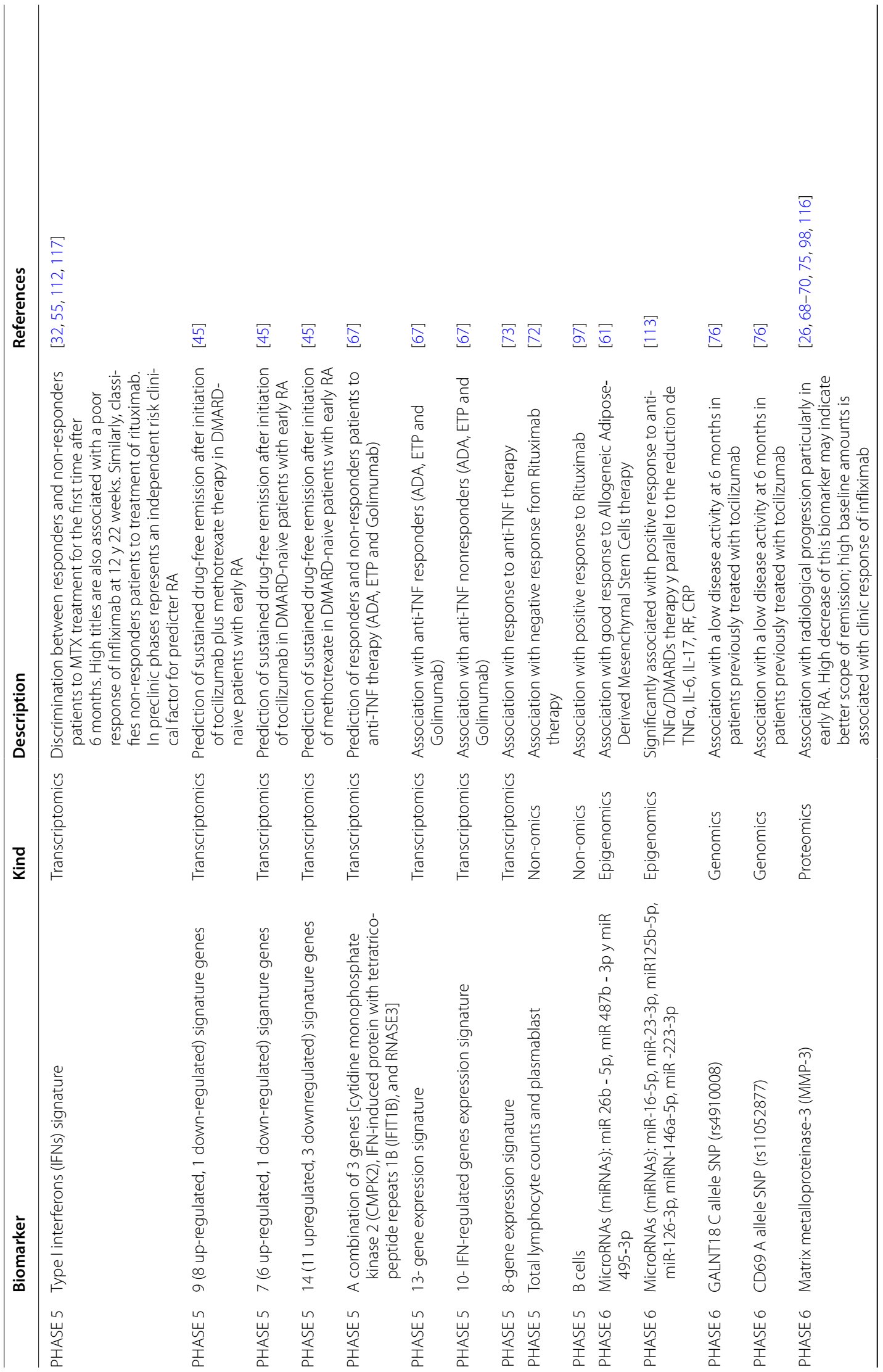




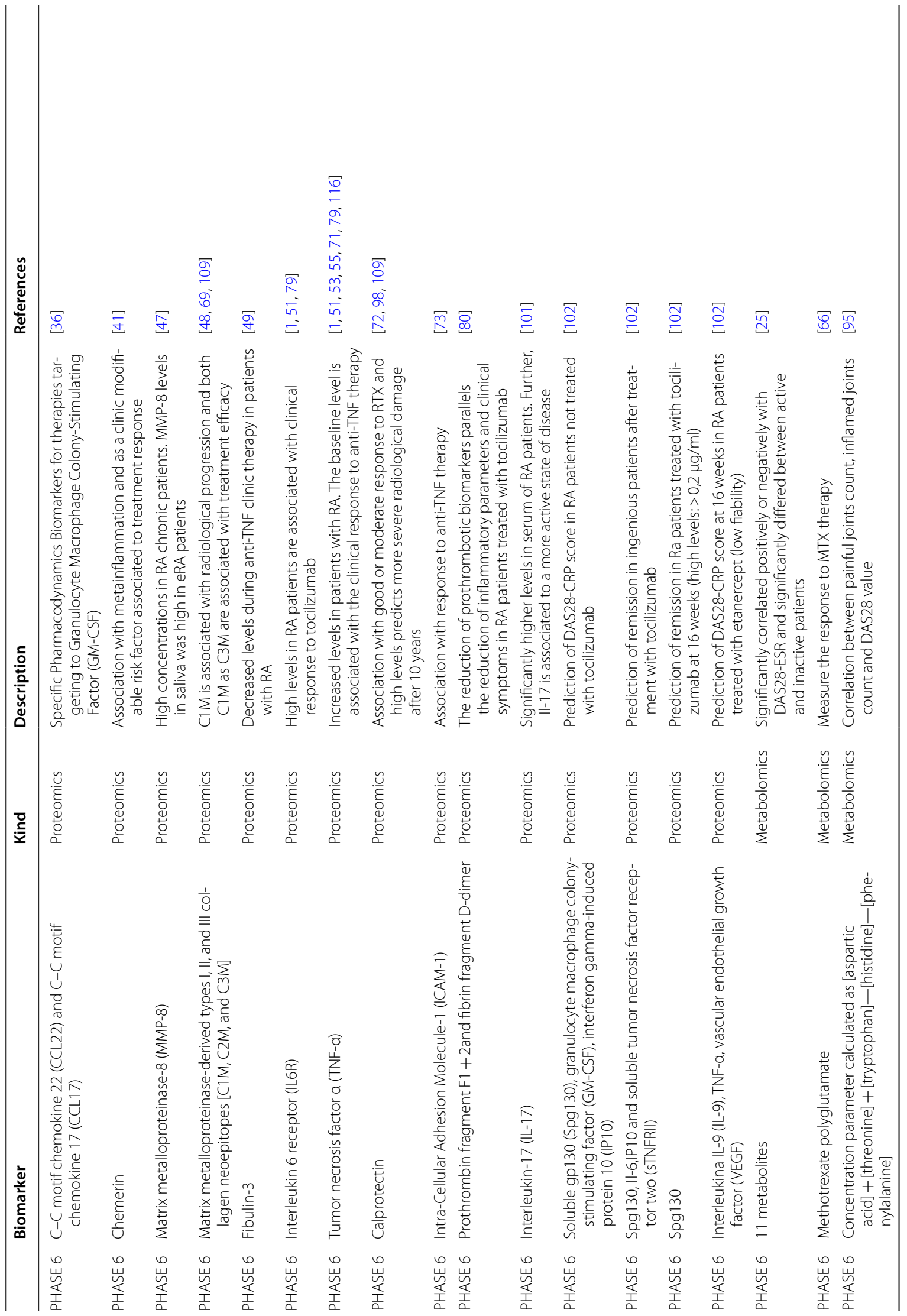




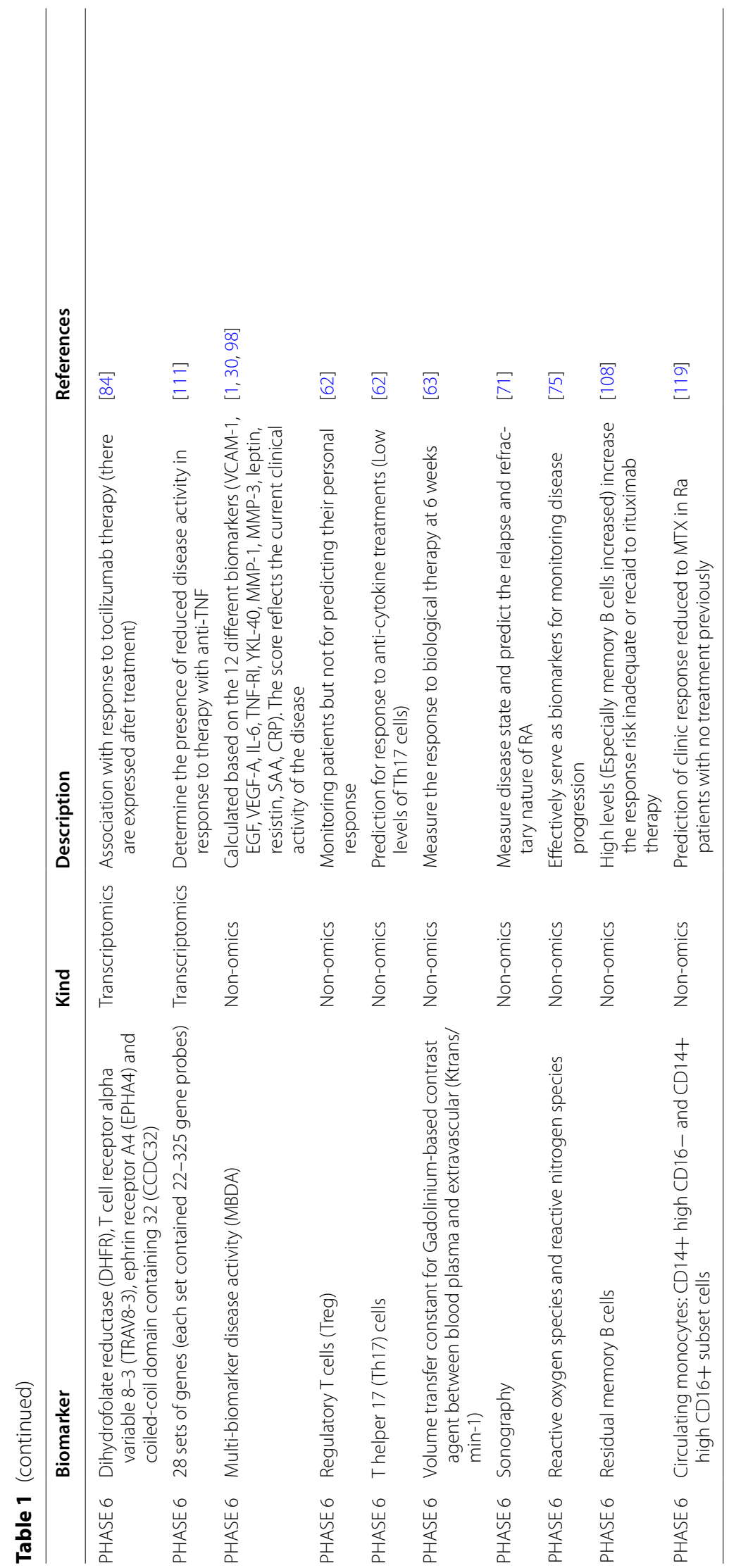


Table 2 Advantage of discovering and using new biomarkers in patients with rheumatoid arthritis

\begin{tabular}{|c|c|c|}
\hline Aim & Function & Advantage \\
\hline \multirow[t]{3}{*}{ Prevention } & Susceptibility & Identification of individuals likely to develop RA \\
\hline & Protection and exposure of risk & Establishment of mechanisms that can favor maintenance of health status and reduce risk factors \\
\hline & Risk assessment & $\begin{array}{l}\text { Determination of causes, characteristics, traits, possible risks and probable occurrence of unwanted } \\
\text { adverse events, as well as their consequences on the onset and development of the disease }\end{array}$ \\
\hline \multirow[t]{6}{*}{ Diagnosis } & Stratification & Classification of RA patients in different groups to make decisions \\
\hline & Early diagnosis & Identification of the early state of the disease and contain more successfully its progressive progress \\
\hline & Better diagnosis & Establishment of the disease with certainty \\
\hline & Prognostic value & $\begin{array}{l}\text { Forecast of disease development and support the therapeutic decision making and clinical benefit from } \\
\text { a therapeutic intervention }\end{array}$ \\
\hline & Predictive value & Measure patient's responsiveness to treatment \\
\hline & Relevance and need & Establishment of time and appropriate measures to address the disease \\
\hline \multirow[t]{4}{*}{ Treatment } & Proper selection & Choice of appropriate drug for specific RA patient \\
\hline & Response evaluation & Determination of the efficacy of anti-rheumatic therapy \\
\hline & Disease activity monitoring & $\begin{array}{l}\text { Identification of the existence of problematic situations or good evolution of disease and its possible } \\
\text { interventions }\end{array}$ \\
\hline & Safety & Prevention and/or reduction of side effects that the response to treatment can produce \\
\hline \multirow[t]{4}{*}{ Value chain } & Therapeutic alternatives & Evaluation of recent therapies different from traditional ones \\
\hline & Development of new drugs & Identification of new therapeutic targets \\
\hline & Clinical trials optimization & Reduction of costs and time in development of new drugs \\
\hline & Test development & Improvement of the opportunity and the therapeutic window of medical care \\
\hline
\end{tabular}

- Application in clinical practice. It is probably the biggest challenge for clinical application of biomarkers. There is currently a large number of scientific publications on the discovery of new biomarkers, however, the number of biomarkers applied in clinical practice is very low.

- Accessibility, repeatability, and technical validation.

- Validation times. Time from discovery of a biomarker til its validation in clinical practice is usually extensive due to different established requirements.

- Results processing and interpretation. As use of omic technologies grows, it becomes necessary to be able to disseminate and handle a large amount of data that increases in parallel and ensures an added value for patients. Normally, physicians usually focus on a single issue since addressing other technologies would be complicated. In most cases, biomarkers are specific to a population, so it is necessary to establish biomarkers for each group of patients.

- Legal and regulatory matters. Although processes have been initiated to set policies regarding the issue of biomarkers, there are still too many legal gaps to consider.

Process of health care needs parameters to evaluate effectiveness and safety of pharmacotherapy. In this context, biomarkers are an excellent information tool for prevention, diagnosis, identifying progression of disease, selection of treatment and assessment of response to therapy (pharmacodynamics), as well as applications in experimental evaluation [17].

Therefore, it is useful in the application of disease diagnosis, prognostic factor, choice and monitoring of the best possible treatment, and evaluation of therapeutics in a simple, minimally invasive way and without additional risk for the patient [127]. The rapid growth of technological tools, the progression in advances in validation and elucidation of processes and procedures in molecular biology, analytical chemistry and bioinformatics have increased the application of biomarkers in research and later in clinical practice, highlighting omic biomarkers: transcriptomics, genomics, proteomics and metabolomics [128].

Usefulness of using biomarkers for health contributes to selection of medicines, evaluation of progression of diseases and their treatment. In same way, technological developments make it possible for implemented biomarkers to adjust more and more to the concept of an ideal biomarker; that is, they are increasingly specific and fundamental in the development of different biomedical disciplines, Allow the development of strategies and policies that include patients with rheumatoid arthritis and improve their quality of life.

The clinic importance of the biomarkers in RA is still uncertain. This diagnosis is still based on clinical findings and blood tests with non-omic biomarkers. There are 
many associations that are not totally useful for the diagnosis of RA through omic-biomarkers. Although most of them are related to the characteristics of the disease and their possible outcomes, it has not been possible to perform the diagnostic process with biomarkers alone. However, the usefulness of biomarkers could be established as predictors of disease and outcomes. This could be beneficial in determining the natural history of patients depending on the stage of the disease by personalizing each case.

Therefore, we provide an overview of the pharmacogenomics of RA and the possibility of using omic biomarkers with potential to be used in clinical practice and to support pharmacotherapeutic decisions in order to improve response and safety to treatment.

The relevance of this study lies in providing the possibility to encourage the investigation of omic biomarkers -selected for their biological importance in AR- either in pharmacokinetic and pharmacodynamic processes, to provide additional tools that facilitate the identification of individuals at risk of suffering adverse events or individuals likely to fail treatment. Therefore, it is expected that the information generated can be used in daily clinical practice, helping to choose the best therapeutic option, at the right time with the least possible risk (greater effectiveness and safety) in patients with rheumatoid arthritis [8].

\section{Conclusions}

Globally, there is not a totally effective medication in all patients, and each individual has a different response to drug treatment. This could be explained due to a modification in pharmacokinetics and pharmacodynamics properties of drugs related with genetic environmental conditions. In this context, the investigation of omic biomarkers has been more successful in the identification and explanation of the alteration of pharmacological response, compared to investigations of candidate genes of disease. Therefore, this paper should make a contribution to the selection of the best therapeutic management in patients with RA according to the phase of disease and is a basis to continue the research aimed at the identification of omic biomarkers according to stage of RA and treatment phase.

As observed in this systematic review, in the last decade a great effort has been made to find omic biomarkers capable of predicting the response to therapy in a patient with rheumatoid arthritis. Many biomarkers have been explored and, even though several omic biomarkers have been identified, there are limitations with respect to their specificity, ease of sampling, representativeness, and stability to predict response. Thus, more comprehensive research is still needed in the identification of omic biomarkers in different phases of rheumatoid arthritis with promising next-generation sequencing and nuclear magnetic resonance techniques.

\section{Acknowledgements}

Antioquia University; Colciencias Colombia; University Hospital Virgin of Macarena, Sevilla Spain; Artmédica IPS, Medellín, Colombia.

\section{Authors' contributions}

YPO and PA developed the original idea for this manuscript. YPO, PA, and DT carried out the review and analysis of the articles included. YPO, MAC, VM, and JCDC have contributed to the write the fist manuscript draf. Finally, all authors participated in the drafted the manuscritp. All authors read and approved the final mansucript.

\section{Funding}

The author(s) received no financial support for the research, authorship, and/ or publication of this article.

\section{Declarations}

Competing interests

Authors declare they do not have any conflict of interest.

\section{Author details}

${ }^{1}$ Antioquia University, Medellín, Colombia. ${ }^{2}$ University Hospital Virgin of Macarena, Sevilla, Spain. ${ }^{3}$ Artmédica IPS, Medellín, Colombia. ${ }^{4}$ Pharmacogenomic Center, Medellín, Colombia. ${ }^{5} 41009$ Sevilla, Spain.

Received: 25 January 2021 Accepted: 18 March 2021

Published online: 31 May 2021

References

1. Takeuchi T. Biomarkers as a treatment guide in rheumatoid arthritis. Clin Immunol. 2018;186:59-62. https://doi.org/10.1016/j.clim.2017.07.019.

2. Atkinson AJ, Colburn WA, DeGruttola VG, DeMets DL, Downing GJ, Hoth DF, et al. Biomarkers and surrogate endpoints: preferred definitions and conceptual framework. Clin Pharmacol Ther. 2001;69(3):89-95. https:// doi.org/10.1067/mcp.2001.113989.

3. Nakamura S, Suzuki K, lijima H, Hata Y, Lim CR, Ishizawa Y, et al. Identification of baseline gene expression signatures predicting therapeutic responses to three biologic agents in rheumatoid arthritis: a retrospective observational study. Arthritis Res Ther. 2016;18(1):1-12. https://doi. org/10.1186/s13075-016-1052-8.

4. Arora A, Mahajan A, Spurden D, Boyd H, Porter D. Long-term drug survival of TNF inhibitor therapy in RA patients: a systematic review of european national drug registers. Int J Rheumatol. 2013. https://doi. org/10.1155/2013/764518.

5. Agarwal SK, Glass RJ, Shadick NA, Coblyn JS, Anderson RJ, Maher NE, et al. Predictors of discontinuation of tumor necrosis factor inhibitors in patients with rheumatoid arthritis. J Rheumatol. 2008;35(9):1737-44.

6. Hirata S, Dirven L, Shen Y, Centola M, Cavet G, Lems WF, et al. A multibiomarker score measures rheumatoid arthritis disease activity in the BeSt study. Rheumatology. 2013;52(7):1202-7. https://doi.org/10.1093/ rheumatology/kes362.

7. Ortega, F. Estrategias analíticas en la investigación de nuevos biomarcadores. Monografía XXX: Biomarcadores: Analítica, Diagnóstico y Terapéutica. 2010:13-54.

8. Puentes Osorio Y, Amariles Muñoz P, Aristizábal Bernal BH, Pinto Peñaranda LF, Calleja Hernández MA. Pharmacogenomics of etanercept, infliximab, adalimumab and methotrexate in rheumatoid arthritis. A structured review. Rev colomb reumatol. 2018;25(1):22-37. https:// doi.org/10.1016/j.rcreu.2017.08.004 (ISSN 0121-8123).

9. Nuez F, Carrillo JM. Los marcadores genéticos en la mejora vegetal. Valencia: Universitat Politécnica de Valencia; 2000.

10. U.S. Food \& Drug Administration. U.S. Food \& Drug administration. Biomarker qualification-Collaborative effort to qualify a drug development 
tool. FDA Case Study. 2017. https://www.fda.gov/media/104459/downl oad

11. Amur S, LaVange L, Zineh I, Buckman-Garner S, Woodcock J. Biomarke qualification: toward a multiple stakeholder framework for biomarker development, regulatory acceptance, and utilization. Clin Pharmacol Ther. 2015;98:34-46. https://doi.org/10.1002/cpt.136.

12. Dorcely B, Katz K, Jagannathan R, Chiang SS, Oluwadare B, Goldberg IJ, Bergman M. Novel biomarkers for prediabetes, diabetes, and associated complications. Diabetes Metab Syndr Obes Targets Ther. 2017;10:34561. https://doi.org/10.2147/DMSO.S100074.

13. Roberts SG, Blute ML, Bergstralh EJ, Slezak JM, Zincke H. PSA doubling time as a predictor of clinical progression after biochemical failure following radical prostatectomy for prostate cancer. Mayo Clin Proc. 2001;76(6):576-81. https://doi.org/10.4065/76.6.576.

14. Lee CM, Lee SS, Lee JM, Cho HC, Kim WS, Kim HJ, et al. Early monitoring for detection of antituberculous drug-induced hepatotoxicity. Korean J Intern Med. 2016;31(1):65-72. https://doi.org/10.3904/kjim.2016.31.1.65.

15. Kheyfets VO, Dunning J, Truong U, Ivy DD, Hunter KA, Shandas R Assessment of $\mathrm{N}$-terminal prohormone B-type natriuretic peptide as a measure of vascular and ventricular function in pediatric pulmonary arterial hypertension. Pulm Circ. 2015;5(4):658-66. https://doi.org/10. 1086/683697.

16. Margolis AR, Porter AL, Staresinic CE, Ray CA. Impact of an extended International Normalized Ratio follow-up interval on Healthcare Use among veteran patients on stable warfarin doses. Am J Health Syst Pharm. 2019;76(22):1848-52. https://doi.org/10.1093/ajhp/zxz209.

17. Lock EA, Bonventre JV. Biomarkers in translation; past, present and future. Toxicology. 2008;245(3):163-6. https://doi.org/10.1016/j.tox. 2007.12.004.

18. Amariles P, Faus MJ, Sabater D, Machuca M, Martínez-Martínez F. Atención farmacéutica seguimiento farmacoterapéutico y parámetros de efectividad y seguridad de la farmacoterapia. El Farmacéutico. 2006;362:84-100.

19. Mun S, Lee J, Park A, Kim HJ, Lee YJ, Son H, et al. Proteomics approach for the discovery of rheumatoid arthritis biomarkers using mass spectrometry. Int J Mol Sci. 2019;20(18):4368. https://doi.org/10.3390/ijms2 0184368.

20. Romo-García MF, Bastian Y, Zapata-Zuñiga M, Macías-Segura N, Castillo-Ortiz JD, Lara-Ramírez EE, et al. Identification of putative miRNA biomarkers in early rheumatoid arthritis by genome-wide microarray profiling: a pilot study. Gene. 2019;720:144081. https://doi.org/10. 1016/j.gene.2019.144081.

21. Bernardes M, Madureira A, Oliveira A, Martins MJ, Lucas R, Costa L, et al. Coronary artery calcium score in female rheumatoid arthritis patients: Associations with apolipoproteins and disease biomarkers. Int J Rheum Dis. 2019;22(10):1841-56. https://doi.org/10.1111/1756-185x.13685.

22. Chen Q, Chen D, Li D. Platelet/lymphocyte, lymphocyte/monocyte, and neutrophil/lymphocyte ratios as biomarkers in patients with rheumatoid arthritis and rheumatoid arthritis-associated interstitial lung disease. Med Sci Monit. 2019;25:6474-81. https://doi.org/10.12659/ MSM.916583.

23. Klimenta B, Nefic H, Prodanovic N, Jadric R, Hukic F. Association of biomarkers of inflammation and HLA-DRB1 gene locus with risk of developing rheumatoid arthritis in females. Rheumatol Int. 2019;39(12):2147-57. https://doi.org/10.1007/s00296-019-04429-y.

24. Nys G, Cobraiville G, Servais AC, Malaise MG, De Seny D, Fillet M. Targeted proteomics reveals serum amyloid A variants and alarmins S100A8-S100A9 as key plasma biomarkers of rheumatoid arthritis. Talanta. 2019;2019(204):507-17. https://doi.org/10.1016/J.TALANTA.2019. 06.044 .

25. Sasaki C, Hiraishi T, Oku T, Okuma K, Suzumura K, Hashimoto M, et al. Metabolomic approach to the exploration of biomarkers associated with disease activity in rheumatoid arthritis. PLOS ONE. 2019:14(7):e0219400. https://doi.org/10.1371/journal.pone.0219400.

26. Rinaudo-Gaujous M, Blasco-Baque V, Miossec P, Gaudin P, Farge P, Roblin $X$, et al. Infliximab induced a dissociated response of severe periodontal biomarkers in rheumatoid arthritis patients. J Clin Med. 2019;8(5):751. https://doi.org/10.3390/jcm8050751.

27. Alivernini S, Bruno D, Tolusso B, Bui L, Petricca L, Gigante MR, et al. Differential synovial tissue biomarkers among psoriatic arthritis and rheumatoid factor/anti-citrulline antibody-negative rheumatoid arthritis. Arthr Res Ther. 2019;21(1):116. https://doi.org/10.1186/ s13075-019-1898-7.

28. Huang Y, Zheng S, Wang R, Tang C, Zhu J, Li J. CCL5 and related genes might be the potential diagnostic biomarkers for the therapeutic strategies of rheumatoid arthritis. Clin Rheumatol. 2019;38(9):2629-35. https://doi.org/10.1007/s10067-019-04533-1.

29. Ferreiro-lglesias A, Montes A, Perez-Pampin E, Cañete JD, Raya E, MagroCheca C, et al. Evaluation of 12 GWAS-drawn SNPs as biomarkers of rheumatoid arthritis response to TNF inhibitors A potential SNP association with response to etanercept. PLoS ONE. 2019;14(2):e0213073. https://doi.org/10.1371/journal.pone.0213073.

30. Hambardzumyan K, Bolce RJ, Wallman JK, Van Vollenhoven RF, Saevarsdottir S. Serum biomarkers for prediction of response to methotrexate monotherapy in early rheumatoid arthritis: results from the SWEFOT trial. J Rheumatol. 2019;46(6):555-63. https://doi.org/10.3899/jrheum. 180537.

31. Carlson AK, Rawle RA, Wallace CW, Adams E, Greenwood MC, Bothner B, June RK. Global metabolomic profiling of human synovial fluid for rheumatoid arthritis biomarkers. Clin Exp Rheumatol. 2019;37(3):393-9.

32. Plant D, Maciejewski M, Smith S, Nair N, Hyrich K, Ziemek D, Barton A, Verstappen $\mathrm{S}$. Profiling of gene expression biomarkers as a classifier of methotrexate nonresponse in patients with rheumatoid arthritis. Artritis Rheumatol. 2019;71:678-84. https://doi.org/10.1002/art.40810.

33. Singh A, Patro PS, Aggarwal A. MicroRNA-132, miR-146a, and miR-155 as potential biomarkers of methotrexate response in patients with rheumatoid arthritis. Clin Rheumatol. 2018;38(3):877-84. https://doi. org/10.1007/s10067-018-4380-z.

34. Zhang R, Yang X, Wang J, Han L, Yang A, Zhang J, et al. Identification of potential biomarkers for differential diagnosis between rheumatoid arthritis and osteoarthritis via integrative genome-wide gene expression profiling analysis. Mol Med Rep. 2019;19(1):30-40. https://doi.org/ 10.3892/mmr.2018.9677.

35. Chen Q, Zhang X, Xiong Y, Chen C, Lv S. The CD25+/CD4+ T cell ratio and levels of $\mathrm{CII}, \mathrm{CIX}$ and $\mathrm{CXI}$ antibodies in serum may serve as biomarkers of pristane-induced arthritis in rats and Rheumatoid Arthritis in humans. Comp Biochem Physiol C: Toxicol Pharmacol. 2018;2018(217):25-31. https://doi.org/10.1016/j.cbpc.2018.11.013.

36. Guo X, Wang S, Godwood A, Close D, Ryan PC, Roskos LK, White WI. Pharmacodynamic biomarkers and differential effects of TNF- and GM-CSF-targeting biologics in rheumatoid arthritis. Int J Rheum Dis. 2019;22(4):646-53. https://doi.org/10.1111/1756-185X.13395.

37. Zhang C, Li L, Zhang G, Chen K, Lu A. Deciphering potential correlations between new biomarkers and pattern classification in Chinese medicine by bioinformatics: two examples of rheumatoid arthritis. Chin J Integr Med. 2018. https://doi.org/10.1007/s11655-018-2571-8.

38. Shervington L, Darekar A, Shaikh M, Mathews R, Shervington A. Identifying reliable diagnostic/predictive biomarkers for rheumatoid arthritis. Biomarker insights. 2018;13:1177271918801005. https://doi.org/10. $1177 / 1177271918801005$.

39. Luo Q, Zhang L, Li X, Fu B, Deng Z, Qing C, et al. Identification of circular RNAs hsa_circ_0044235 in peripheral blood as novel biomarkers for rheumatoid arthritis. Clin Exp Immunol. 2018;194(1):118-24. https://doi. org/10.1111/cei.13181.

40. Ben Achour W, Bouaziz M, Mechri M, Zouari B, Bahlous A, Abdelmoula $L$, et al. A cross sectional study of bone and cartilage biomarkers: correlation with structural damage in rheumatoid arthritis. Libyan J Med. 2018;13(1):1512330. https://doi.org/10.1080/19932820.2018.1512330

41. Tolusso B, Gigante MR, Alivernini S, Petricca L, Fedele AL, Di Mario C, et al. Chemerin and PEDF are metaflammation-related biomarkers of disease activity and obesity in rheumatoid arthritis. Front Med. 2018;5:207. https://doi.org/10.3389/fmed.2018.00207.

42. Martinez-Prat L, Nissen MJ, Lamacchia C, Bentow C, Cesana L, RouxLombard P, et al. Comparison of serological biomarkers in rheumatoid arthritis and their combination to improve diagnostic performance. Front Immunol. 2018;9:1113. https://doi.org/10.3389/fimmu.2018. 01113.

43. Dunaeva M, Blom J, Thurlings R, Pruijn G. Circulating serum miR-223-3p and miR-16-5p as possible biomarkers of early rheumatoid arthritis. Clin Exp Immunol. 2018;193(3):376-85. https://doi.org/10.1111/cei.13156.

44. Teitsma XM, Jacobs JWG, Concepcion AN, Pethö-Schramm A, Borm MEA, van Laar JM, et al. Explorative analyses of protein biomarkers in 
patients with early rheumatoid arthritis achieving sustained drug-free remission after treatment with tocilizumab- or methotrexate-based strategies: from transcriptomics to proteomics. Clin Exp Rheumatol. 2018;36(6):976-83.

45. Teitsma XM, Jacobs J, Mokry M, Borm M, Pethö-Schramm A, Van Laar $J M$, et al. Identification of differential co-expressed gene networks in early rheumatoid arthritis achieving sustained drug-free remission after treatment with a tocilizumab-based or methotrexate-based strategy. Arthritis Res Ther. 2017;19(1):170. https://doi.org/10.1186/ s13075-017-1378-x.

46. Kurowska W, Kuca-Warnawin E, Radzikowska A, Jakubaszek M, Maślińska M, Kwiatkowska B, Maśliński W. Monocyte-related biomarkers of rheumatoid arthritis development in undifferentiated arthritis patients - a pilot study. Reumatologia. 2018;56(1):10-6. https://doi.org/10.5114/ reum.2018.74742.

47. Äyräväinen L, Heikkinen AM, Kuuliala A, Ahola K, Koivuniemi R, Laasonen $\mathrm{L}$, et al. Inflammatory biomarkers in saliva and serum of patients with rheumatoid arthritis with respect to periodontal status. Ann Med. 2018;50(4):333-44. https://doi.org/10.1080/07853890.2018. 1468922.

48. Kjelgaard-Petersen CF, Platt A, Braddock M, Jenkins MA, Musa K, Graham E, et al. Translational biomarkers and ex vivo models of joint tissues as a tool for drug development in rheumatoid arthritis. Arthritis Rheumatol. 2018;70(9):1419-28. https://doi.org/10.1002/art.40527.

49. Kopec-Medrek M, Kucharz EJ. Fibulin-3 and other cartilage metabolism biomarkers in relationship to calprotectin (MRP8/14) and disease activity in rheumatoid arthritis patients treated with anti-TNF therapy. Adv Clin Exp Med. 2018;27(3):383-9. https://doi.org/10.17219/acem/68362.

50. Fang G, Zhang QH, Tang Q, Jiang Z, Xing S, Li J, Pang Y. Comprehensive analysis of gene expression and DNA methylation datasets identify valuable biomarkers for rheumatoid arthritis progression. Oncotarget. 2017;9(3):2977-83. https://doi.org/10.18632/oncotarget.22918.

51. Kaneko Y, Takeuchi T. Targeted antibody therapy and relevant novel biomarkers for precision medicine for rheumatoid arthritis. Int Immunol. 2017;29(11):511-7. https://doi.org/10.1093/intimm/dxx055.

52. Wang JR, Gao WN, Grimm R, Jiang S, Liang Y, Ye H, et al. A method to identify trace sulfated IgG N-glycans as biomarkers for rheumatoid arthritis. Nat Commun. 2017;8(1):1-4. https://doi.org/10.1038/ s41467-017-00662-w.

53. Atzeni F, Talotta R, Masala IF, Bongiovanni S, Boccassini L. Biomarkers in rheumatoid arthritis. Isr Med Assoc J. 2017;19(8):512-6.

54. Nass FR, Skare TL, Goeldner I, Nisihara R, Messias-Reason IT, Utiyama SRR. Analysis of four serum biomarkers in rheumatoid arthritis: association with extra articular manifestations in patients and arthralgia in relatives. Revista Brasileira de Reumatologia (English Edition). 2017;57(4):286-93. https://doi.org/10.1016/j.rbre.2016.03.001.

55. Finckh A, Alpizar-Rodriguez D, Roux-Lombard P. Value of biomarkers in the prevention of rheumatoid arthritis. Clin Pharmacol Ther. 2017;102(4):585-7. https://doi.org/10.1002/cpt.727.

56. Siloşi I, Boldeanu L, Biciuşcă V, Bogdan M, Avramescu C, Taisescu C, et al. Serum biomarkers for discrimination between hepatitis C-related arthropathy and early rheumatoid arthritis. Int J Mol Sci. 2017:18(6):1304. https://doi.org/10.3390/ijms18061304.

57. Nakken B, Papp G, Bosnes V, Zeher M, Nagy G, Szodoray P. Biomarkers for rheumatoid arthritis: from molecular processes to diagnostic applications-current concepts and future perspectives. Immunol Lett. 2017;189:13-8. https://doi.org/10.1016/j.imlet.2017.05.010.

58. Torices S, Alvarez-Rodríguez L, Varela I, Muñoz P, Balsa A, López-Hoyos $M$, et al. Evaluation of Toll-like-receptor gene family variants as prognostic biomarkers in rheumatoid arthritis. Immunol Lett. 2017;187:35-40. https://doi.org/10.1016/j.imlet.2017.04.011.

59. Huang QL, Zhou FJ, Wu CB, Xu C, Qian WY, Fan DP, Cai XS. Circulating biomarkers for predicting infliximab response in rheumatoid arthritis: a systematic bioinformatics analysis. Med Sci Monit. 2017;23:1849-55. https://doi.org/10.12659/msm.900897.

60. Thanapati S, Ganu M, Giri P, Kulkarni S, Sharma M, Babar A, et al. Impaired NK cell functionality and increased TNF-a production as biomarkers of chronic chikungunya arthritis and rheumatoid arthritis. Human Immunol. 2017;78(4):370-4. https://doi.org/10.1016/j.humimm. 2017.02.006.
61. Mallinson DJ, Dunbar DR, Ridha S, Sutton ER, De la Rosa O, Dalemans W, Lombardo E. Identification of potential plasma microRNA stratification biomarkers for response to allogeneic adipose-derived mesenchymal stem cells in rheumatoid arthritis. Stem Cells Transl Med. 2017;6(4):1202-6. https://doi.org/10.1002/sctm.16-0356.

62. Salomon S, Guignant C, Morel P, Flahaut G, Brault C, Gourguechon C, et al. Th17 and CD24hiCD27+ regulatory B lymphocytes are biomarkers of response to biologics in rheumatoid arthritis. Arthritis Res Ther. 2017;19(1):33. https://doi.org/10.1186/s13075-017-1244-x.

63. Waterton JC, Ho M, Nordenmark LH, Jenkins M, DiCarlo J, Guillard $\mathrm{G}$, et al. Repeatability and response to therapy of dynamic contrastenhanced magnetic resonance imaging biomarkers in rheumatoid arthritis in a large multicentre trial setting. Eur Radiol. 2017;27(9):36628. https://doi.org/10.1007/s00330-017-4736-9.

64. Fan W, Wang W, Wu J, Ma L, Guo J. Identification of CD4+ T-cell-derived CD161+ CD39+ and CD39+CD73+ microparticles as new biomarkers for rheumatoid arthritis. Biomark Med. 2017;1 1(2):107-16. https://doi. org/10.2217/bmm-2016-0261.

65. Van Erp SJH, Verheul MK, Levarht EWN, Van der Reijden JJ, Van der Heijde D, Van Gaalen FA, et al. Absence of serological rheumatoid arthritis biomarkers in inflammatory bowel disease patients with arthropathies. Eur J Gastroenterol Hepatol. 2017;29(3):345-8. https://doi.org/10.1097/ meg.00000000000000805.

66. Brown PM, Pratt AG, Isaacs JD. Mechanism of action of methotrexate in rheumatoid arthritis and the search for biomarkers. Nat Rev Rheumatol. 2016;12(12):731-42. https://doi.org/10.1038/nrrheum.2016.175.

67. Wright HL, Cox T, Moots RJ, Edwards SW. Neutrophil biomarkers predict response to therapy with tumor necrosis factor inhibitors in rheumatoid arthritis. J Leukoc Biol. 2017;101:785-95. https://doi.org/10.1189/ jlb.5A0616-258R.

68. Khojah HM, Ahmed S, Abdel-Rahman MS, Alkhalil KM, Hamza AB. Vitamin $\mathrm{K}$ homologs as potential biomarkers for disease activity in patients with rheumatoid arthritis. J Bone Miner Metab. 2016;35(5):529-35. https://doi.org/10.1007/s00774-016-0785-4.

69. Boyapati A, Msihid J, Fiore S, Van Adelsberg J, Graham NMH, Hamilton JD. Sarilumab plus methotrexate suppresses circulating biomarkers of bone resorption and synovial damage in patients with rheumatoid arthritis and inadequate response to methotrexate: A biomarker study of mobility. Arthritis Res Ther. 2016;18(1):1-12. https://doi.org/10.1186/ s13075-016-1132-9.

70. Ghavipour M, Sotoudeh G, Tavakoli E, Mowla K, Hasanzadeh J, Mazloom Z. Pomegranate extract alleviates disease activity and some blood biomarkers of inflammation and oxidative stress in Rheumatoid Arthritis patients. Eur J Clin Nutr. 2016;71(1):92-6. https://doi.org/10.1038/ejcn. 2016.151.

71. Chen S, Zheng Q, Liu H, Zeng J, Ye Z, Su Y, Lv G. Sonography is superior to serum-based biomarkers for measuring disease status in experimental rheumatoid arthritis. J Ultrasound Med. 2016;35(10):2223-30. https://doi.org/10.7863/ultra.15.10044.

72. Stradner MH, Dejaco C, Brickmann K, Graninger WB, Brezinschek HP. A combination of cellular biomarkers predicts failure to respond to rituximab in rheumatoid arthritis: a 24-week observational study. Arthritis Res Ther. 2016;18(1):190. https://doi.org/10.1186/s13075-016-1091-1.

73. Folkersen L, Brynedal B, Diaz-Gallo LM, Ramsköld D, Shchetynsky $\mathrm{K}$, Westerlind $\mathrm{H}$, et al. Integration of known DNA, RNA and protein biomarkers provides prediction of anti-TNF response in rheumatoid arthritis: results from the COMBINE study. Mol Med. 2016;22:322-8. https://doi.org/10.2119/molmed.2016.00078.

74. Gavrilă BI, Ciofu C, Stoica V. Biomarkers in Rheumatoid Arthritis, what is new? J Med Life. 2016:9(2):144-8.

75. Khojah HM, Ahmed S, Abdel-Rahman MS, Hamza AB. Reactive oxygen and nitrogen species in patients with rheumatoid arthritis as potential biomarkers for disease activity and the role of antioxidants. Free Radical Biol Med. 2016;97:285-91. https://doi.org/10.1016/j.freeradbiomed. 2016.06.020.

76. Maldonado-Montoro M, Cañadas-Garre M, González-Utrilla A, PlazaPlaza JC, Calleja-Hernández MA. Genetic and clinical biomarkers of tocilizumab response in patients with rheumatoid arthritis. Pharmacol Res. 2016;111:264-71. https://doi.org/10.1016/j.phrs.2016.06.016.

77. Yuan TL, Chen J, Tong YL, Zhang Y, Liu YY, Wei JC, et al. Serum heme oxygenase-1 and BMP-7 are potential biomarkers for bone metabolism in 
patients with rheumatoid arthritis and ankylosing spondylitis. BioMed Res Int. 2016. https://doi.org/10.1155/2016/7870925.

78. Sebastian A, Alzain MA, Asweto CO, Song H, Cui L, Yu X, et al. Glycan biomarkers for rheumatoid arthritis and its remission status in $\mathrm{Han}$ Chinese patients. OMICS J Integr Biol. 2016;20(6):343-51. https://doi. org/10.1089/omi.2016.0050.

79. Tsujimoto K, Hata A, Fujita M, Hatachi S, Yagita M. Presepsin and procalcitonin as biomarkers of systemic bacterial infection in patients with rheumatoid arthritis. Int J Rheum Dis. 2018;21(7):1406-13. https://doi. org/10.1111/1756-185X.12899

80. Gualtierotti R, Ingegnoli F, Griffini S, Grovetti E, Meroni PL, Cugno M. Prothrombotic biomarkers in patients with rheumatoid arthritis: the beneficial effect of IL-6 receptor blockade. Clin Exp Rheumatol. 2016;34(3):451-8.

81. Ortea I, Roschitzki B, López-Rodríguez R, Tomero EG, Ovalles JG, LópezLongo J, et al. Independent candidate serum protein biomarkers of response to adalimumab and to infliximab in rheumatoid arthritis: an exploratory study. PLoS ONE. 2016;11(4):e0153140. https://doi.org/10. 1371/journal.pone.0153140.

82. Batliwalla FM, Li W, Ritchlin CT, Xiao X, Brenner M, Laragione T, et al. Microarray analyses of peripheral blood cells identifies unique gene expression signature in psoriatic arthritis. Mol Med. 2005;11(1-12):21-9. https://doi.org/10.2119/2006-00003.Gulko.

83. Anderson AE, Pratt AG, Sedhom MA, Doran JP, Routledge C, Hargreaves $B$, et al. IL-6-driven STAT signalling in circulating CD4+ lymphocytes is a marker for early anticitrullinated peptide antibody-negative rheumatoid arthritis. Ann Rheum Dis. 2016;75(2):466-73. https://doi.org/10. 1136/annrheumdis-2014-205850.

84. Hogan VE, Holweg CTJ, Choy DF, Kummerfeld SK, Hackney JA, Teng YKO, et al. Pretreatment synovial transcriptional profile is associated with early and late clinical response in rheumatoid arthritis patients treated with rituximab. Ann Rheum Dis. 2012;71(11):1888-94. https:// doi.org/10.1136/annrheumdis-2011-201115.

85. Drynda S, Ringel B, Kekow M, Kühne C, Drynda A, Glocker MO, et al. Proteome analysis reveals disease-associated marker proteins to differentiate RA patients from other inflammatory joint diseases with the potential to monitor anti-TNFa therapy. Pathol Res Pract. 2004;200(2):165-71. https://doi.org/10.1016/j.prp.2004.02.011.

86. Lauridsen MB, Bliddal H, Christensen R, Danneskiold-Samsøe B, Bennett $\mathrm{R}$, Keun $\mathrm{H}$, et al. ${ }^{1} \mathrm{H}$ NMR spectroscopy-based interventional metabolic phenotyping: a cohort study of rheumatoid arthritis patients. J Proteome Res. 2010;9(9):4545-53. https://doi.org/10.1021/pr1002774.

87. Madsen RK, Lundstedt T, Gabrielsson J, Sennbro CJ, Alenius GM, Moritz $\mathrm{T}$, et al. Diagnostic properties of metabolic perturbations in rheumatoid arthritis. Arthritis Res Ther. 2011;13(1):1-9. https://doi.org/10.1186/ ar3243.

88. Young SP, Kapoor SR, Viant MR, Byrne JJ, Filer A, Buckley CD, et al. The impact of inflammation on metabolomic profiles in patients with arthritis. Arthritis Rheum. 2013;65(8):2015-23. https://doi.org/10.1002/ art.38021

89. Anderson JR, Chokesuwattanaskul S, Phelan MM, Welting T, Lian LY, Peffers MJ, Wright HL. 1H NMR metabolomics identifies underlying inflammatory pathology in osteoarthritis and rheumatoid arthritis synovial joints. J Proteome Res. 2018;17(11):3780-90. https://doi.org/10. 1021/acs.jproteome.8b00455.

90. Kapoor SR, Filer A, Fitzpatrick MA, Fisher BA, Taylor PC, Buckley CD, et al. Metabolic profiling predicts response to anti-tumor necrosis factor a therapy in patients with rheumatoid arthritis. Arthritis Rheum. 2013;65(6):1448-56. https://doi.org/10.1002/art.37921.

91. Priori R, Casadei L, Valerio M, Scrivo R, Valesini G, Manetti C. ${ }^{1} \mathrm{H}-\mathrm{NMR}$ based metabolomic study for identifying serum profiles associated with the response to etanercept in patients with rheumatoid arthritis. PLoS ONE. 2015;10(11):e0138537. https://doi.org/10.1371/journal.pone. 0138537.

92. Knevel R, Klein K, Somers K, Ospelt C, Houwing-Duistermaat JJ, Van Nies JA, et al. Identification of a genetic variant for joint damage progression in autoantibody-positive rheumatoid arthritis. Ann Rheum Dis. 2014;73(11):2038-46. https://doi.org/10.1136/annrh eumdis-2013-204050.

93. Park YJ, Yoo SA, Hwang D, Cho CS, Kim WU. Identification of novel urinary biomarkers for assessing disease activity and prognosis of rheumatoid arthritis. Exp Mol Med. 2016;48(2):e211. https://doi.org/10. 1038/emm.2015.120.

94. Di Sante G, Tolusso B, Fedele AL, Gremese E, Alivernini S, Nicolò C, et al. Collagen specific T-cell repertoire and HLA-DR alleles: biomarkers of active refractory rheumatoid arthritis. EBioMedicine. 2015;2(12):203745. https://doi.org/10.1016/j.ebiom.2015.11.019.

95. Smolenska Z, Smolenski RT, Zdrojewski Z. Plasma concentrations of amino acid and nicotinamide metabolites in rheumatoid arthritispotential biomarkers of disease activity and drug treatment. Biomarkers. 2016;21(3):218-24. https://doi.org/10.3109/1354750x.2015.11307 46.

96. Masi AT, Rehman AA, Jorgenson LC, Smith JM, Aldag JC. Sexual dimorphisms of adrenal steroids, sex hormones, and immunological biomarkers and possible risk factors for developing rheumatoid arthritis. Int J Endocrinol. 2015. https://doi.org/10.1155/2015/929.

97. Tony HP, Roll P, Mei HE, Blümner E, Straka A, Gnuegge L, Dörner T. Combination of $B$ cell biomarkers as independent predictors of response in patients with RA treated with rituximab. Clin Exp Rheumatol. 2015;33(6):887-94.

98. Yilmaz-Oner S, Ozen G, Can M, Atagunduz P, Direskeneli H, Inanc N . Biomarkers in remission according to different criteria in patients with rheumatoid arthritis. J Rheumatol. 2015;42(11):2066-70. https://doi.org/ 10.3899/jrheum.150478.

99. Nass FR, Skare TL, Goeldner I, Nisihara R, Messias-Reason IJ, Utiyama SRR. Association of complement factor B allotypes and serum biomarkers in rheumatoid arthritis patients and their relatives. Int J Immunogenet. 2015;42(6):439-44. https://doi.org/10.1111/iji.12232.

100. Shen L, Zhang H, Zhou X, Liu R. Association between polymorphisms of interleukin 12 and rheumatoid arthritis associated biomarkers in a Chinese population. Cytokine. 2015;76(2):363-7. https://doi.org/10. 1016/j.cyto.2015.09.007.

101. Brzustewicz E, Bryl E. The role of cytokines in the pathogenesis of rheumatoid arthritis - practical and potential application of cytokines as biomarkers and targets of personalized therapy. Cytokine. 2015;76(2):527-36. https://doi.org/10.1016/j.cyto.2015.08.260.

102. Uno K, Yoshizaki K, Iwahashi M, Yamana J, Yamana S, Tanigawa M, Yagi K. Pretreatment prediction of individual rheumatoid arthritis patients' response to anti-cytokine therapy using serum cytokine/chemokine/ soluble receptor biomarkers. PLOS ONE. 2015;10(7):e0132055. https:// doi.org/10.1371/journal.pone.0132055.

103. Cui J, Stahl EA, Saevarsdottir S, Miceli C, Diogo D, Trynka G, et al. Genome-wide association study and gene expression analysis identifies CD84 as a predictor of response to etanercept therapy in rheumatoid arthritis. PLoS Genet. 2013;9(3):e1003394. https://doi.org/10.1371/journ al.pgen.1003394.

104. Acosta-Colman I, Palau N, Tornero J, Fernández-Nebro A, Blanco F, González-Alvaro I, et al. GWAS replication study confirms the association of PDE3A-SLCO1C1 with anti-TNF therapy response in rheumatoid arthritis. Pharmacogenomics. 2013;14(7):727-34. https://doi.org/10. 2217/pgs.13.60

105. Julià A, Fernandez-Nebro A, Blanco F, Ortiz A, Cañete JD, Maymó J, et al. A genome-wide association study identifies a new locus associated with the response to anti-TNF therapy in rheumatoid arthritis. Pharmacogenomics J. 2015;16(2):147-50. https://doi.org/10.1038/tpj.2015.31.

106. Cui J, Saevarsdottir S, Thomson B, Padyukov L, Van der Helm-van Mil AH, Nititham J, et al. Rheumatoid arthritis risk allele PTPRC is also associated with response to anti-tumor necrosis factor alpha therapy. Arthritis Rheum. 2010;62(7):1849-61. https://doi.org/10.1002/art.27457.

107. Ferreiro-Iglesias A, Montes A, Perez-Pampin E, Cañete JD, Raya E, MagroCheca C, et al. Replication of PTPRC as genetic biomarker of response to TNF inhibitors in patients with rheumatoid arthritis. Pharmacogenomics J. 2015;16(2):137-40. https://doi.org/10.1038/tpj.2015.29.

108. Adlowitz DG, Barnard J, Biear JN, Cistrone C, Owen T, Wang W, et al. Expansion of activated peripheral blood memory $B$ cells in rheumatoid arthritis, impact of B cell depletion therapy, and biomarkers of response. PLoS ONE. 2015;10(6):e0128269. https://doi.org/10.1371/journal.pone. 0128269.

109. McArdle A, Flatley B, Pennington SR, FitzGerald O. Early biomarkers of joint damage in rheumatoid and psoriatic arthritis. Arthritis Res Ther. 2015;17(1):141. https://doi.org/10.1186/s13075-015-0652-z. 
110. Ally MM, Hodkinson B, Meyer PW, Musenge E, Tintinger GR, Tikly $M$, Anderson R. Circulating anti-citrullinated peptide antibodies, cytokines and genotype as biomarkers of response to diseasemodifying antirheumatic drug therapy in early rheumatoid arthritis. BMC Musculoskelet Disord. 2015;16(1):130. https://doi.org/10.1186/ s12891-015-0587-1.

111. Oswald M, Curran ME, Lamberth SL, Townsend RM, Hamilton JD, Chernoff DN, et al. Modular analysis of peripheral blood gene expression in rheumatoid arthritis captures reproducible gene expression changes in tumor necrosis factor responders. Arthritis Rheumatol. 2015;67(2):34451. https://doi.org/10.1002/art.38947.

112. Verheul MK, Fearon U, Trouw LA, Veale DJ. Biomarkers for rheumatoid and psoriatic arthritis. Clin Immunol. 2015;161(1):2-10. https://doi.org/ 10.1016/j.clim.2015.04.005.

113. Castro-Villegas C, Pérez-Sánchez C, Escudero A, Filipescu I, Verdu M, Ruiz-Limón P, et al. Circulating miRNAs as potential biomarkers of therapy effectiveness in rheumatoid arthritis patients treated with anti-TNFa. Arthritis Res Ther. 2015;17(1):49. https://doi.org/10.1186/ s13075-015-0555-z.

114. Doyle TJ, Patel AS, Hatabu H, Nishino M, Wu G, Osorio JC, et al. Detection of rheumatoid arthritis-interstitial lung disease is enhanced by serum biomarkers. Am J Respir Crit Care Med. 2015;191(12):1403-12. https://doi.org/10.1164/rccm.201411-19500C.

115. Ahmed U, Anwar A, Savage RS, Costa ML, Mackay N, Filer A, et al. Biomarkers of early stage osteoarthritis, rheumatoid arthritis and musculoskeletal health. Sci Rep. 2015;5:9259. https://doi.org/10.1038/srep0 9259 .

116. Mirtaheri E, Pourghassem Gargari B, Kolahi S, Dehghan P, AsghariJafarabadi M, Hajalilou M, et al. Effects of alpha-lipoic acid supplementation on inflammatory biomarkers and matrix metalloproteinase-3 in rheumatoid arthritis patients. J Am Coll Nutr. 2015;34(4):310-7. https:// doi.org/10.1080/07315724.2014.910740.

117. Rodríguez-Carrio J, López P, Suárez A. Type I IFNs as biomarkers in rheumatoid arthritis: towards disease profiling and personalized medicine. Clin Sci. 2015;128(8):449-64. https://doi.org/10.1042/cs20140554.

118. Ge L, Huang Y, Zhang H, Liu R, Xu N. Association between polymorphisms of interleukin 10 with inflammatory biomarkers in East Chinese Han patients with rheumatoid arthritis. Joint Bone Spine. 2015;82(3):182-6. https://doi.org/10.1016/j.jbspin.2014.11.007.

119. Chara L, Sánchez-Atrio A, Pérez A, Cuende E, Albarrán F, Turrión A, et al. The number of circulating monocytes as biomarkers of the clinical response to methotrexate in untreated patients with rheumatoid arthritis. J Transl Med. 2015;13(1):1-10. https://doi.org/10.1186/ s12967-014-0375-y.

120. Han BK, Kuzin I, Gaughan JP, Olsen NJ, Bottaro A. Baseline CXCL10 and CXCL13 levels are predictive biomarkers for tumor necrosis factor inhibitor therapy in patients with moderate to severe rheumatoid arthritis: a pilot, prospective study. Arthritis Res Ther. 2016;2016(18):93. https://doi.org/10.1186/s13075-016-0995-0.

121. Pratesi F, Migliorini P. Something old, something new: biomarkers in rheumatoid arthritis. J Rheumatol. 2014;41(11):2091-3. https://doi.org/ 10.3899/jrheum.141069.

122. Chen J, Doyle TJ, Liu Y, Aggarwal R, Wang X, Shi Y, et al. Biomarkers of rheumatoid arthritis-associated interstitial lung disease. Arthritis Rheumatol. 2015;67(1):28-38. https://doi.org/10.1002/art.38904.

123. Rodriguez-Rodriguez L, Lopez-Mejias R, Fernandez-Gutierrez B, Balsa A, Gonzalez-Gay M, Martin J. Rheumatoid arthritis: genetic variants as biomarkers of cardiovascular disease. Curr Pharm Des. 2014;21(2):182-201. https://doi.org/10.2174/1381612820666140825123407.

124. Cuchacovich M, Bueno D, Carvajal R, Bravo N, Aguillón JC, Catalán D, Soto L. Clinical parameters and biomarkers for anti-TNF treatment prognosis in rheumatoid arthritis patients. Clin Rheumatol. 2014;33(12):1707-14. https://doi.org/10.1007/s10067-014-2756-2.

125. Cheng Y, Chen Y, Sun X, Li Y, Huang C, Deng H, Li Z. Identification of potential serum biomarkers for rheumatoid arthritis by high-resolution quantitative proteomic analysis. Inflammation. 2014;37(5):1459-67. https://doi.org/10.1007/s10753-014-9871-8.

126. Cohen S, Emery P. The American College of Rheumatology/European League Against Rheumatism criteria for the classification of rheumatoid arthritis: a game changer. Arthritis Rheum. 2010;62(9):2592-4. https:// doi.org/10.1002/art.27583.

127. Poste G. Bring on the biomarkers. Nature. 2011;469(7329):156-7. https://doi.org/10.1038/469156.

128. Vainio H. Review use of biomarkers in risk assessment. Int J Hyg Environ Health. 2001;204(2-3):91-102. https://doi.org/10.1078/ 1438-4639-00088.

\section{Publisher's Note}

Springer Nature remains neutral with regard to jurisdictional claims in published maps and institutional affiliations.
Ready to submit your research? Choose BMC and benefit from:

- fast, convenient online submission

- thorough peer review by experienced researchers in your field

- rapid publication on acceptance

- support for research data, including large and complex data types

- gold Open Access which fosters wider collaboration and increased citations

- maximum visibility for your research: over $100 \mathrm{M}$ website views per year

At BMC, research is always in progress.

Learn more biomedcentral.com/submissions 